Review

\title{
The Impact of Bacteria of the Genus Bacillus upon the Biodamage/Biodegradation of Some Metals and Extensively Used Petroleum-Based Plastics
}

\author{
Nataliia Tkachuk ${ }^{1, *(1)}$ and Liubov Zelena ${ }^{2}$ \\ 1 Department of Biology, Natural and Mathematical Faculty, T.H. Shevchenko National University “Chernihiv \\ Colehium", 53 Hetman Polubotok Str., 14013 Chernihiv, Ukraine \\ 2 Department of Physiology of Industrial Microorganisms, Danylo Zabolotny Institute of Microbiology and \\ Virology, National Academy of Sciences of Ukraine, 154 Acad. Zabolotny Str., 03143 Kyiv, Ukraine: \\ zelenalyubov@gmail.com \\ * Correspondence: nataliia.smykun@gmail.com
}

check for updates

Citation: Tkachuk, N.; Zelena, L. The Impact of Bacteria of the Genus Bacillus upon the Biodamage/

Biodegradation of Some Metals and Extensively Used Petroleum-Based Plastics. Corros. Mater. Degrad. 2021, 2, 531-553. https://doi.org/10.3390/ cmd2040028

Academic Editor: Daniel

John Blackwood

Received: 30 July 2021

Accepted: 22 September 2021

Published: 26 September 2021

Publisher's Note: MDPI stays neutral with regard to jurisdictional claims in published maps and institutional affiliations.

Copyright: (c) 2021 by the authors. Licensee MDPI, Basel, Switzerland. This article is an open access article distributed under the terms and conditions of the Creative Commons Attribution (CC BY) license (https:// creativecommons.org/licenses/by/ $4.0 /)$.

\begin{abstract}
This paper tackles bacteria of the genus Bacillus as both biodamaging/biodegrading and biocontrolling agents. The article addresses the said bacteria's ability to form biofilms and corrosive, antimicrobial and antibiofilm proactive compounds, primarily, siderophores. Their role depends on the species, microorganism strain, production of antimicrobial substances, biofilm formation, and the type of damaged material. The bacteria under analysis have demonstrated the ability to cause as well as inhibit biodamage. The involvement of bacteria of the genus Bacillus in microbiologically influenced corrosion processes is determined by the production of corrosive metabolites and the impact of certain bioelectrochemical mechanisms. Lipopeptides generated by Bacillus subtilis (surfactin, iturin and fengycin) are capable of modifying surfaces' hydrophobic properties and impacting the microbes' adhesion to surfaces. Produced by Bacillus velezensis, the siderophore bacillibactin at a high concentration is capable of inhibiting the formation of bacterial biofilms, thus slowing down the degradation of materials. Further study of siderophores as green inhibitors of microbiologically influenced corrosion may be promising as the said compounds possess antibiofilm-forming properties and high-intensity inhibitory capabilities.
\end{abstract}

Keywords: Bacillus; biodamage of materials; biodegradation of materials; biological control

\section{Introduction}

In the context of rapid development of technology and construction, as well as creation of new materials, the issue of material biodamage and appropriate protection appears as the focus of substantial research [1-3]. Biodamage (biodegradation) of materials can be responsible for human-made ecological catastrophes [1]. Bactericides have traditionally been used to prevent microbiologically influenced corrosion (MIC), although they pose health, safety and environmental problems [4]. Derivatives of substandard pesticides are proposed as inhibitors of MIC [5].

On the other hand, the processes of biodegradation involve chemical elements in geochemical cycles leading to the removal of xenobiotics from the environment [3].

As an alternative, the use of microorganisms (biocides) is suggested as a protective means against biodamage [6]. However, the research in the field of biological control has been conducted under laboratory conditions and its effectiveness has not yet been confirmed [7].

Sulfate-reducing bacteria (SRB) are most commonly associated with MIC, while little attention has thus far been paid to the representatives of other taxonomic groups [7]. Bacteria of the genus Bacillus deserve attention both as biodamaging/biodegradable and biocontrolling agents, as they are able to form corrosive compounds [8], polymer-degrading compounds [9], antimicrobials [10] and antibiofilm-forming compounds [11]. Therefore, 
this paper provides analysis of Bacillus's impact upon some metals and extensively used synthetic plastics as biodamage/biodegradation agents.

\section{Representatives of the Genus Bacillus as Corrosive Bacteria}

A range of mechanisms have been considered to explain MIC [12]: (1) cathodic depolarization theory; (2) attack by sulfides; (3) direct electron uptake by the microorganisms, including redox mediators; 4 ) the impact of microorganisms on the mineralogy of surface films. Most of these mechanisms are based on SRB and were meant for anaerobic environments. However, none of the said mechanisms is truly explanatory [12]. In addition to these mechanisms, as Moura et al. state [13], the formation of corrosive media is associated with the generation of acid or with the impact of bacteria. Bacillus is one of the representative microorganisms for MIC research [8]. In the case of metal corrosion, Bacillus sp. account for $10 \%$ of the total number of taxonomic units among the isolated heterotrophic bacteria [14]. In layers of rust on steel plates that were submerged in sea water, the genera Bacillus and Vibrio were dominant, accountings for $53.06 \%$ of the total number [15]. In a number of microbiological, physiological, biochemical and molecular genetic studies, ammonifying bacteria were isolated from the samples of the soil ferrosphere and identified as Bacillus simplex strain ChNPU F1 and Fictibacillus sp. strain ChNPU ZVB1 [16]. Much attention has been paid to the corrosive effects of Bacillus on metals, but the mechanism of degradation is still unclear and controversial [8]. Microbial damage to metals depends on the species and strain of bacteria of the genus Bacillus. The potential of two hydrocarbon-degrading bacteria (Gram-positive bacterium, Bacillus cereus (B. cereus) strain ACE4, and Gram-negative bacterium, Serratia marcescens strain ACE2) to corrode aluminum alloy AA 2024 was determined by using electrochemical impedance spectroscopy and surface analysis (implementing electronic microscopy, energy-dispersive X-ray spectroscopy, atomic force microscopy and Fourier-transform infrared spectroscopy techniques) [17]. The authors explain the marked corrosion effect of $B$. cereus by the presence of catalase and cytochrome oxidase enzymes.

The active agent in the biofilm formation is the bacterium B. cereus strain GU 812900 which was isolated from a stainless steel test panel by Bragadeeswaran et al. [18]. The authors proved that the corrosion rate depended on the concentration of the exopolysaccharides within this microorganism. In particular, the corrosion rate increased as the concentration of the exopolysaccharides grew.

The corrosive activity of B. cereus and Bacillus licheniformis (B. licheniformis) involved in biodamage of materials is determined by their being nitrate-reducing bacteria $[19,20]$. MIC bioelectrochemical mechanisms of B. licheniformis and B. cereus can be notated as the following reactions $[19,20]$ (Table 1):

Table 1. Reactions of MIC bioelectrochemical mechanisms of B. licheniformis and B. cereus [19,20].

\begin{tabular}{cc}
\hline Reaction Type & Reaction Equation \\
\hline Oxidation & $\mathrm{Fe} \rightarrow \mathrm{Fe}^{2+}+2 \mathrm{e}^{-}$ \\
\hline \multirow{2}{*}{ Reduction } & $2 \mathrm{NO}_{3}{ }^{-}+10 \mathrm{e}^{-}+12 \mathrm{H}^{+} \rightarrow \mathrm{N}_{2}+6 \mathrm{H}_{2} \mathrm{O}$ \\
\cline { 2 - 2 } & $\mathrm{NO}_{3}^{-}+8 \mathrm{e}^{-}+10 \mathrm{H}^{+} \rightarrow \mathrm{NH}_{4}^{+}+3 \mathrm{H}_{2} \mathrm{O}$ \\
\hline
\end{tabular}

The B. licheniformis biofilm on a C1018 (UNS G10180) carbon steel coupon surface was observed via a scanning electronic microscope (SEM) [19]. In this study, pitting data indicate that $B$. licheniformis is more aggressive than typical SRB.

Electrochemical and surface analyses and live/dead staining were performed by Wan et al. [20] to study the corrosion of X80 pipeline steel in the presence of B. cereus. As the results of SEM and live/dead staining testify, some B. cereus appeared to adhere to X80 steel. Electrochemical impedance spectroscopy showed that B. cereus could accelerate the corrosion of X80 steel. In addition, surface morphology observations indicated that $B$. 
cereus could accelerate pitting corrosion in X80 steel [20]. The corrosive effect of B. cereus strain SNB4 on mild steel coupons is shown by Bano et al. [21].

The synergistic effect of slime-forming bacteria $B$. cereus var. mycoides strain CECT 193 and SRB Desulfovibrio desulfuricans strain DSM 642 was investigated by Santana et al. [22]. This study discusses B. cereus's stimulation of the development of sulfatereducing bacteria and, accordingly, intensifying the tendency to progress corrosion [22]. A seawater system with sodium lactate containing both investigated strains demonstrated a clear decrease in the polarization resistance throughout the test duration (14 days). The value of the corrosion potential tends to negative values to a greater extent than the other systems, which indicates the synergic effect of both bacteria. The authors noted that $B$. cereus var. mycoides is a facultative anaerobic bacterium and, therefore, it favors the development of SRB and consequently determines a greater tendency towards corrosion after an initial phase of enhanced protection [22].

The influence of Bacillus mycoides (B. mycoides) upon samples of $\mathrm{Zn}, \mathrm{Al}$ and steel was studied over 2 years under controlled humidity $(97 \%)$ and temperature $\left(26^{\circ} \mathrm{C}\right)$ [23]. The corrosion activity was evaluated periodically by measurements of polarization resistance via electrochemical impedance spectroscopy. Acceleration of zinc corrosion under the influence of B. mycoides is discussed in [23].

Surface analysis methods, a mass loss method and electrochemical tests were employed to investigate the corrosion behavior of Q235 steel under the synergistic effect of Thiobacillus thiooxidans (T. thiooxidans) and Bacillus [24]. The study explicates that circular corrosion poles, much different from the ones in the single-bacterium cultures, appeared on the surface of the sample immersed in the mixed culture. The corrosion rate identified via the mass loss method in the microbial association was close to the average values typical for a single-bacterium system. Electrochemical impedance spectroscopy shows that two time constants existed in the T. thiooxidans + Bacillus system after 2 days of immersion, where the corrosion resistance of the film was initially enhanced and then weakened [24]. Karn et al. [25] recorded different levels of peroxidase and catalase enzyme production by strains of Bacillus sp. In a specific range, the enzymes can induce corrosion, however, this is a strain characteristic [25]. In the experiment, Bacillus paralicheniformis (B. paralicheniformis) strain 720 R2A_5R_0.5, isolated as a part of the International Space Station microbial community, was aerobically and anaerobically incubated together with Cupriavidus metallidurans strain pH5_R2_1_II_A and Cutibacterium avidum strain R7A_A1_IIIA with untreated aluminum alloy platelets, anodized aluminum alloy platelets and pieces of NOMEX®fabric [26]. The NOMEX®fabric itself remained intact over a period of 6 weeks, but served as an excellent attachment surface for B. paralicheniformis biofilms. B. paralicheniformis adhered to neither the untreated nor anodized aluminum alloy. However, the untreated aluminum alloy which was co-incubated with B. paralicheniformis showed only some signs of corrosion compared to the untreated negative control incubated in sterile medium [26]. Lipopeptides produced by B. subtilis (surfactin, iturin and fengycin) decreased the hydrophobicity of Teflon [27].

Table 2 provides generalizations on the involvement of the genus Bacillus in the processes of biodamage of metals and alloys.

Therefore, the bacteria of the genus Bacillus are representatives of microorganisms investigated in the processes of MIC of metals and alloys in both monocultures and associative cultures. The involvement of these bacteria in MIC processes is associated with the production of corrosive metabolites and the involvement of bioelectrochemical mechanisms. 
Table 2. Diversity of members of the genus Bacillus involved in biodamage of metals and alloys.

\begin{tabular}{ccc}
\hline Representative of the Genus Bacillus & Research Material & References \\
\hline \multirow{2}{*}{ Bacillus cereus } & Al 2024 Aeronautical alloy & {$[18]$} \\
\cline { 2 - 3 } & Mild steel & {$[20]$} \\
\cline { 2 - 3 } & Stainless steel & {$[18]$} \\
\cline { 2 - 3 } & AISI 304 stainless steel & {$[22]$} \\
\hline Bacillus licheniformis/paralicheniformis & C1018 carbon steel & {$[19]$} \\
\hline Bacillus mycoides & Zn & {$[23]$} \\
\hline \multirow{2}{*}{ Bacillus subtilis } & Teflon & {$[7]$} \\
\hline Bacillus sp. & Q235 steel & {$[27]$} \\
\hline
\end{tabular}

\section{Bacteria of the Genus Bacillus in the Biodegradation of Some Synthetic Plastics}

In this study, we focused on the diversity of bacteria of the genus Bacillus, which biodegrade polyethylene (PE), polypropylene (PP), polystyrene (PS), polyvinyl chloride (PVC), poly (ethylene terephthalate) (PET) and polyurethane (PUR). These polymers are synthesized from fossil hydrocarbons, a non-renewable resource, and comprise more than $90 \%$ of the global total production of polymeric materials [28]. Enzymes released by microorganisms during growth and development act as aggressive media in biodamage of insulating materials [1]. In particular, such compounds are able to produce the bacterium B. mesentericus (B. subtilis), found on polymer coatings [1]. Degradation of polyethylene can be classified as abiotic (caused by temperature and UV irradiation) or biotic (biodegradation caused by the action of microorganisms). Microorganisms modify and consume the polymer, leading to changes in its properties. Bacteria of the genus Bacillus, among other bacterial strains, are involved in the biodegradation of polyethylene $[29,30]$. B. amyloliquefaciens, B. brevis, B. cereus, B. circulans, B. halodenitrificans, B. mycoides, B. pumilus, B. sphericus and $B$. thuringiensis appear to be particularly active agents causing biodegradation of this material. Restrepo-Flórez et al. [29] highlight that although the damage to polyethylene is connected to only one of these two damage modes, both typically act cooperatively in nature [31]. The abiotic mechanisms of deterioration of polyethylene have been described in [31]. The biodegradation of polyethylene and mechanisms associated with this process are analyzed in review publications [29,30]. The biodegradation of polyethylene under normal conditions is extremely slow, while the knowledge of complete metabolic pathways involved in the process, as well as the inventory and structure of respective enzymes, is quite basic [29]. The authors discuss changes of PE in the presence of microorganisms: (1) functional groups on the surface; (2) the surface topography; (3) the hydrophobicity/hydrophilicity of a surface; (4) mechanical properties; (5) crystallinity; (6) molecular weight distribution. It is indicated that the loss of molecular weight and the oxidation of the molecules are the result of synergistic effects caused by biotic and abiotic factors (photo-oxidation or heat treatment) [29]. In particular, thermo-irradiation pretreatment was important for the biodegradation of PE by Bacillus amyloliquefaciens (B. amyloliquefaciens) [32]. Biofilm colonization is the initial step in the degradation of this polymer [29]. Bacteria that form biofilms are capable of producing surfactants, molecules that can mediate the attachment process of microorganisms to a hydrophobic surface [29]. Hydrocarbon polymers are resistant to biodegradation, which results from highly stable $\mathrm{C}-\mathrm{C}$ and $\mathrm{C}-\mathrm{H}$ covalent bonds [33]. Restrepo-Flórez et al. [29] note the theoretical possibility of polyethylene being used as a carbon source for microorganisms, similar to many other hydrocarbons, but subject to the reduction in PE molecular weight by the chemical/biochemical processes. The presence, in some members of the genus Bacillus, of enzymes related to the Pseudomonas putida GPo1 membrane-bound alkane hydroxylase system [34] increases this probability. Such enzymes are involved in a complicated chemical reaction: the regio- and stereospecific 
activation of $\mathrm{C}-\mathrm{H}$ bonds. There are reports that the weight loss of degradable polyethylene (PE with chemical or photoinitiators or both) positively correlated with $\mathrm{CO}_{2}$ emission in the consortium of Pseudomonas frequentans + B. mycoides under the condition of treatments with or without preheating [35]. Based on this, the researchers conclude that the disposal of degradable polyethylene by these bacteria is a source of carbon.

The initial step involves hydroxylation of C-C bonds, generating primary or secondary alcohols, which are further oxidized to aldehydes or ketones, and then to carboxylic acids [36]. Thus, microbial oxidation decreases the number of carbonyl groups due to the formation of carboxylic acids. Carboxylated n-alkanes are analogous to fatty acids, which can be catabolized by bacteria via the $\beta$-oxidation system pathway (Figure 1 ). However, neither the breaking of $\mathrm{C}-\mathrm{C}$ bonds within the backbone of PE polymers nor the generation of long carbon chain carboxylic acid hydrolysis products have been reported [36].

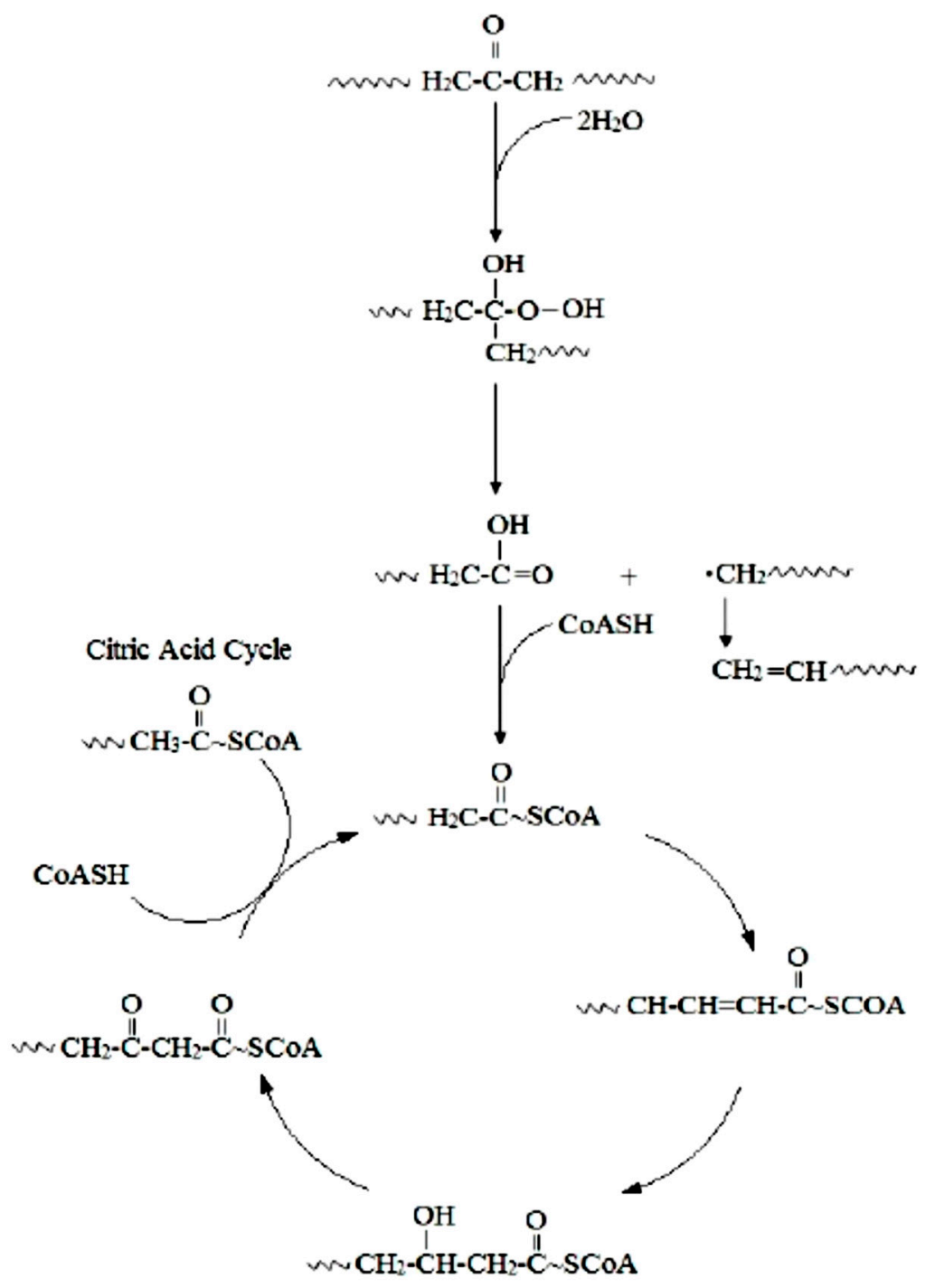

Figure 1. Mechanism for the biodegradation of PE [36].

Thus, bacterial isolates B. amyloliquefaciens contributed to the depolymerization of biodegraded products in extracellular media, indicating the biodegradation process of PE [37]. The participation of B. brevis in PE biodegradation is noted in the work of Wasserbauer et al. [38]. B. cereus degraded UV-irradiated PE associated with a pronounced extracellular production of both laccases and $\mathrm{MnP}$ [39]. Biodegradable properties against PE were also observed for B. cereus strain Ma-Su CECRI-1 [40] and B. cereus strain A5,a [41]. In the latter case, a high biodegradable activity $(35.72 \pm 4.01 \%)$ in relation to PE was 
registered [41]. The ability to biodegrade PE is also inherent to B. subtilis [42]. B. subtilis produced surface active compounds (biosurfactants) that enhance the degradation process of PE [43].

The ability of B. mycoides and B. subtilis (Bacillus species indigenous to the Niger Delta mangrove soil) to biodegrade polyethylene was studied by Ibiene et al. [44].

Bacillus safensis and B. amyloliquefaciens have demonstrated the biodegradable ability for low-density polyethylene thermoplastic. Moreover, B. safensis had better biodegradable ability than B. amyloliquefaciens, shown by the registered weight reduction [45].

It is worth noting that only genus (Bacillus) identification of bacteria has been established in most studies. Thus, in a number of studies, Bacillus sp. are indicated as polyethylene-degrading bacteria [46-51], the ability of which to form a biofilm on the surface of this material and reduce its hydrophobicity by isolated bacteria was noted in the article of Yang et al. [49]. The biofilm formation on the surface of polyethylene and its biodegradation were also observed for B. mycoides [35].

A brief summary of the articles devoted to the biodegradation of PE with the participation of bacteria of the genus Bacillus is presented in Table 3.

Polypropylene was biodegraded by the $B$. flexus + Pseudomonas azotoformans and $B$. flexus $+B$. subtilis associations [52]. Polypropylene was subjected to biodegradation by $B$. cereus [53,54], B. thuringenesis and B. licheniformis [54]. The latter three species are also involved in the biodegradation of polypropylene-poly-L-lactide [54]. Degradation of PP microplastics by B. gottheilii caused a weight loss of $3.6 \%$ after 40 days [55].

Biodegradation of polypropylene has been improved by using polymer blends of carbohydrates, starch or cellulose blends such as that reported for polyethylene and polystyrene [56]. The use of the blends facilitates adhesion of the microorganisms to the surface of the polymer and acts as a co-metabolite. Biodegradation of polycaprolactone blended PP has also been demonstrated using lipase since lipase is well known to degrade the ester linkages of polycaprolactone [56].

Bacillus sp. degrades polystyrene [57-59]. The following studies provide insights into biodegradation of PS caused by B. aryabhattai [60], B. subtilis [61], and B. paralicheniformis [62]. B. cereus and B. gottheilii reduced PS granule weight by $7.4 \%$ and $5.8 \%$, respectively, within 40 days [55]. B. cereus was also noted as a biodegradable PS in [63].

Strains B. subtilis and B. cereus formed biofilm on PET and poly (lactic acid), demonstrating biochemical activity and accelerating biodegradation of both plastic materials [64]. B. cereus was also identified as part of two consortia capable of biofilm formation and PET degradation [65]. B. megaterium formed a biofilm on PET film [28]. Carboxylesterases from B. licheniformis and B. subtilis partially hydrolyzed PET fibers and showed a high activity against PET oligomers [66].

The mechanism of PET biodegradation is demonstrated in Figure 2. The PET-digesting enzyme labeled as PETase converts PET to mono(2-hydroxyethyl) terephthalic acid (MHET), with minimal amounts of terephthalic acid (TPA) and bis(2-hydroxyethyl)-TPA as secondary products [56].

B. flexus has been proved to biodegrade poly (vinyl chloride) (PVC) film [67]. Bacteria of this species have been able to form dense biofilm on the plastic film surface and cause a decrease in the mean molecular weight of the PVC film [67]. Bacillus sp., triggering degradation of PVC, caused weight loss of the material of $0.26 \pm 0.02 \%$ in comparison to initial weights after 90 days [51].

The involvement of bacteria of the genus Bacillus in the biodegradation of polyurethanes is discussed in a review article by G.T. Howard [68]. PUR-degrading bacteria are B. chitinolyticus and B. pumilus [69] and B. subtilis [70-72].

Oxidative degradation has been generally associated with poly(ether-urethane) [73]. This mechanism is illustrated by the following reactions (Table 4). 
Table 3. A summary of the articles on the biodegradation of PE with the participation of bacteria of the genus Bacillus.

\begin{tabular}{|c|c|c|c|c|c|}
\hline $\begin{array}{l}\text { Representative of the } \\
\text { Genus Bacillus }\end{array}$ & Research Material & Preliminary Treatment & Incubation Time & Proposed Biodegradation Mechanisms & References \\
\hline 1 & 2 & 3 & 4 & 5 & 6 \\
\hline Bacillus amiloliquefaciens & Low-density PE (LDPE) & Heat treatment & 60 days & $\begin{array}{l}\text { Depolymerization, various surface chemical changes, } \\
\text { LDPE used as a sole carbon source }\end{array}$ & [37] \\
\hline Bacillus brevis & $\begin{array}{l}\text { PE Bralen NA 7-25; PE Bralen VA 20-12, } \\
\text { SA 200-22; PE Bralen RA 2-19; PE } \\
\text { BralenFA 7-15; PE Liten BB 29; PE Liten } \\
\text { BB 38; Ground PE Liten FB 22-402 }\end{array}$ & Not indicated & $64 \mathrm{~h}$ & $\begin{array}{c}\text { Enzymatic oxidation (monooxygenase hydroxylation } \\
\text { system); oxidation of PE with the formation carbonyl, } \\
\text { ester and hydroxyl groups; changes in the mechanical } \\
\text { properties of PE }\end{array}$ & {$[38]$} \\
\hline Bacillus cereus & $\mathrm{PE}$ & $\begin{array}{l}\text { UV treatment; autoclaving; } \\
\text { surface sterilization }\end{array}$ & 12 weeks & $\begin{array}{l}\text { Enzymatic (laccase and manganese peroxidase) } \\
\text { degradation; the formation of carboxylic acids, } \\
\text { aldehydes, alcohols, esters, ethers, aromatics, alkene } \\
\text { and phenol groups; changes in relative elongation, } \\
\text { relative tensile strength and molecular weight } \\
\text { distribution; UV-treated PE as sole source of carbon is } \\
\text { much better than autoclaved and surface sterilized }\end{array}$ & [39] \\
\hline \multirow[t]{2}{*}{ Bacillus cereus } & $\begin{array}{l}\text { LDPE (24FSO40); oxo-biodegra dable PE } \\
\text { (10\% oxo-biodegra dable additive, } 90 \% \\
\text { PE) }\end{array}$ & $\begin{array}{l}\text { UV-B treatment; heat } \\
\text { treatment }\end{array}$ & 90 days & $\begin{array}{l}\text { Influence of bacterial enzymes (oxidative } \\
\text { (oxidoreductase) and degradative). The utilization of } \\
\text { PE, especially the oxygenated fragments, by bacteria } \\
\text { as their sole source of carbon. The increase in surface } \\
\text { energy and decrease in contact angle; increased } \\
\text { hydrophilicity of PE, which facilitates the bacterial } \\
\text { attachment on the surface of polymer }\end{array}$ & [40] \\
\hline & LDPE & Not indicated & 16 weeks & $\begin{array}{l}\text { No mechanism proposed. There is the formation of } \\
\text { aldehydes and ketones which are intermediate } \\
\text { products of biodegradation of PE }\end{array}$ & [41] \\
\hline Bacillus subtilis & LDPE; HDPE & UV treatment & 30 days & $\begin{array}{l}\text { Treated PE had more weight loss than untreated PE } \\
\text { because UV rays act as an initiator of PE oxidation } \\
\text { which enhances the bacterial degradation. The } \\
\text { addition of biosurfactant (surfactin) of B. subtilis } \\
\text { caused the most efficient loss of PE, which proves the } \\
\text { assistance in attachment of microbes to PE films. } \\
\text { There is the formation of ketone, aldehyde, carboxyl } \\
\text { acids and alcohols after biodegradation }\end{array}$ & [43] \\
\hline
\end{tabular}


Table 3. Cont.

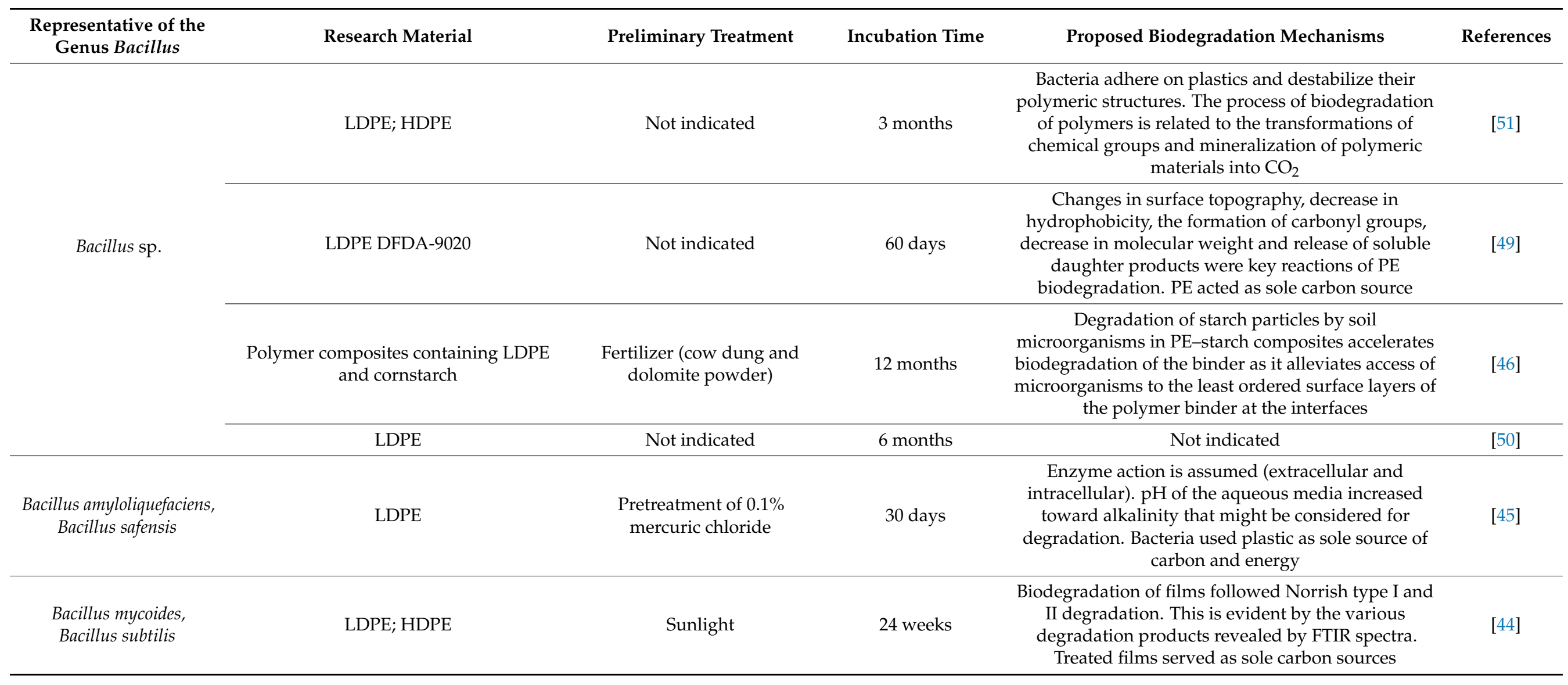


Table 3. Cont.

\begin{tabular}{|c|c|c|c|c|c|}
\hline $\begin{array}{l}\text { Representative of the } \\
\text { Genus Bacillus }\end{array}$ & Research Material & Preliminary Treatment & Incubation Time & Proposed Biodegradation Mechanisms & References \\
\hline $\begin{array}{l}\text { Bacillus sphericus, } \\
\text { Bacillus cereus }\end{array}$ & LDPE; starch-blended LDPE; HDPE & Heat treatment & 12 months & $\begin{array}{l}\text { Abiotic and biotic degradation PE have synergistic } \\
\text { relationship. Thermal treatment plays a vital role in } \\
\text { enhancing the rate of biodegradation. Blends with } \\
\text { starch have a higher weight loss then unblended PE. } \\
\text { The formation and disappearance of ester, keto, } \\
\text { double bond and vinyl groups. Influence of bacteria } \\
\text { increases with wettability of the polymer, decreases } \\
\text { with tensile strength and percentage crystallinity. } \\
\text { Bacillus species utilize PE as carbon source. The } \\
\text { decrease in carbonyl index due to biodegradation } \\
\text { occurs by the Norrish-type mechanism or by the } \\
\text { formation of ester }\end{array}$ & [47] \\
\hline $\begin{array}{l}\text { Bacillus subtilis, Bacillus } \\
\text { cereus, Bacillus lentus }\end{array}$ & PE; plastics & $\begin{array}{l}\text { Organic fertilizers (chicken } \\
\text { droppings, cow dung); } \\
\text { inorganic fertilizer (NPK) }\end{array}$ & 9 months & $\begin{array}{l}\text { No mechanism proposed. The high rate of } \mathrm{CO}_{2} \\
\text { evolution for soils with chicken droppings and cow } \\
\text { dung treatments was noted }\end{array}$ & [42] \\
\hline $\begin{array}{l}\text { Bacillus cereus }+ \\
\text { Bacillus megaterium }+ \\
\text { Bacillus subtilis, } \\
\text { Bacillus borstelensis }\end{array}$ & $\begin{array}{l}\text { LDPE; HDPE films with iron, cobalt and } \\
\text { manganese stearates as pro-oxidant } \\
\text { additives (at } 0.2 \% w / w)\end{array}$ & Thermal and photoaging & 90 days & $\begin{array}{l}\text { The first step of biotic degradation is the thermal and } \\
\text { photochemical oxidation. The material should be } \\
\text { substantially chemically transformed by the action of } \\
\text { the pro-oxidant additives under light and heat, and } \\
\text { thus more susceptible to microbial attack. The second } \\
\text { step is mineralization of materials. It is indicated that } \\
\text { the results are consistent with the oxidative activity of } \\
\text { microorganisms. Cobalt and manganese have high } \\
\text { catalytic effect in the photochemiical degradation } \\
\text { of LDPE }\end{array}$ & [48] \\
\hline $\begin{array}{c}\text { Bacillus mycoides; } \\
\text { Bacillus mycoides }+ \\
\text { Penicillium frequentans }\end{array}$ & UV- and oxi-degradable PE & Heat treatment & 45 days & $\begin{array}{l}\text { The formation of the Penicillium-Bacillus biofilm and } \\
\text { its architecture help in the effective transport of the } \\
\text { bacterium, colonization of PE and subsequent } \\
\text { degradation of its surface by enzymatic reactions }\end{array}$ & [35] \\
\hline
\end{tabular}




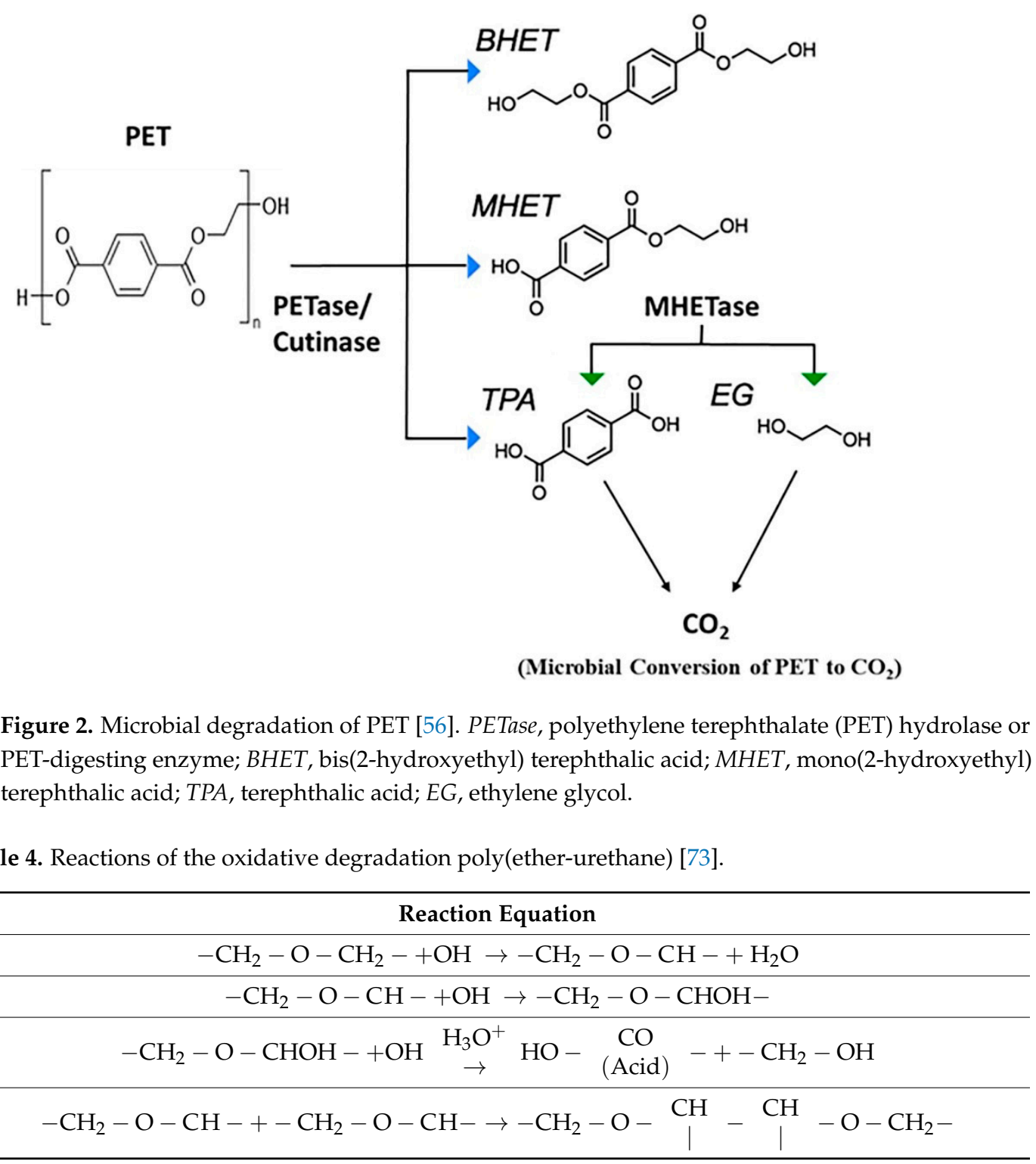

Thus, the reactive oxygen species initiate degradation of polyether urethanes through oxidative attack of the soft segment. This reactive oxygen species abstracts an alphamethylene hydrogen atom from the polyether soft segment. The addition of a hydroxyl radical to the carbon radical forms a hemiacetal, which oxidizes to an ester. Acid hydrolysis of the ester results in chain scission of the soft segment and formation of acid end groups. Significant chain scission results in the solubilization and extraction of low molecular weight degradation products [73].

A similar oxidative mechanism was proposed for hard segment degradation [73]. Oxygen radicals abstract an alpha-methylene hydrogen atom from the chain extender at the urethane. Additional hydroxyl radicals combine with the chain radical to form a highly reactive carbonyl hemiacetal. Oxidative hydrolysis of the carbonyl hemiacetal results in chain scission and formation of an unstable carbamic acid and carboxylic acid end groups [73]. The carbamic acid decarboxylates readily to form a free amine. The mechanism of polyurethane biodegradation with the participation of polyurethane esterases is shown by Mohanan et al. [56] (Figure 3). 


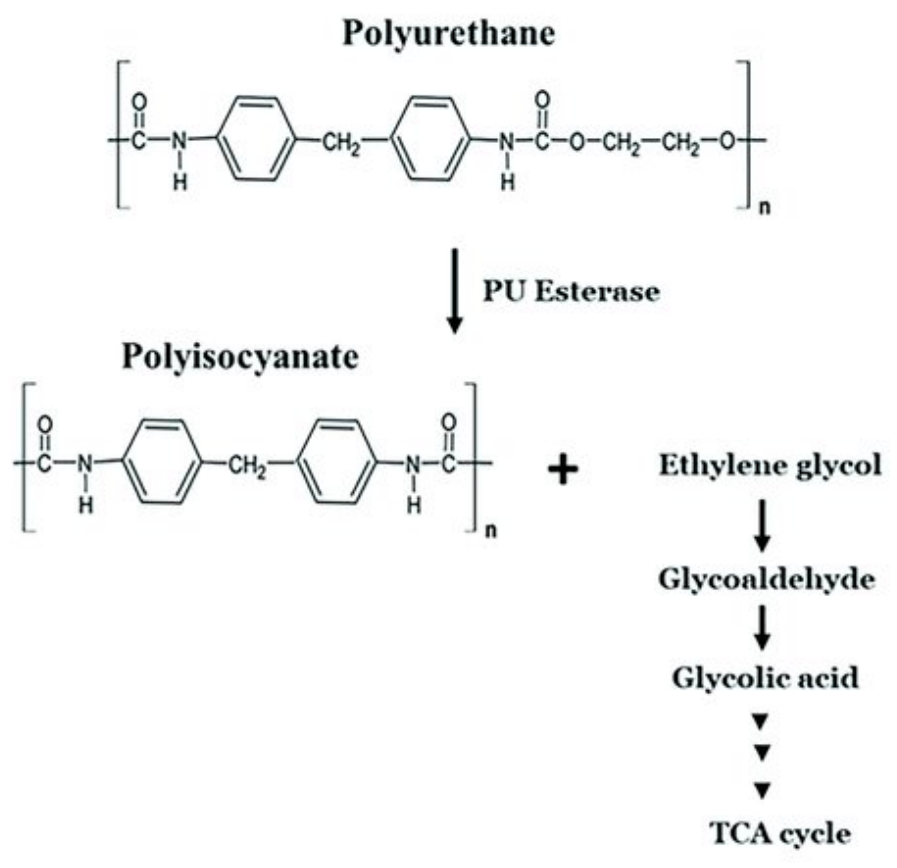

Figure 3. Microbial degradation pathway of polyurethane [56]. TCA cycle: the cycle of tricarboxylic acids. PU esterase: polyurethane esterase.

Ru et al. [74] present the metabolic pathways of degradation of the plastics considered by us (Figure 4 ).

Table 5 shows generalizations the biodiversity of bacteria of the genus Bacillus, which are involved in the biodegradation of synthetic plastics.

Table 5. Diversity of bacteria of the genus Bacillus, which are involved in the biodegradation of synthetic plastics.

\begin{tabular}{|c|c|c|}
\hline Representative of the Genus Bacillus & Research Material & References \\
\hline Bacillus amyloliquefaciens & Polyethylene & {$[29,30,37,45]$} \\
\hline Bacillus aryabhattai & Polystyrene & {$[60]$} \\
\hline Bacillus borstelensis & Polyethylene & [48] \\
\hline Bacillus brevis & Polyethylene & {$[29,30,38]$} \\
\hline \multirow{4}{*}{ Bacillus cereus } & Polyethylene & {$[29,30,39-41]$} \\
\hline & Polypropylene & {$[53,54]$} \\
\hline & Polystyrene & {$[55,63]$} \\
\hline & Poly (ethylene terephthalate) & {$[64,65]$} \\
\hline Bacillus chitinolyticus & Polyurethane & [69] \\
\hline Bacillus circulans & Polyethylene & {$[29,30]$} \\
\hline Bacillus flexus & Poly (vinyl chloride) & [67] \\
\hline \multirow{2}{*}{ Bacillus gottheilii } & Polypropylene & [55] \\
\hline & Polystyrene & [55] \\
\hline Bacillus halodenitrificans & Polyethylene & {$[29,30]$} \\
\hline \multirow{3}{*}{ Bacillus licheniformis/paralicheniformis } & Polypropylene & {$[54]$} \\
\hline & Polystyrene & [62] \\
\hline & Poly (ethylene terephthalate) & [66] \\
\hline
\end{tabular}


Table 5. Cont.

\begin{tabular}{|c|c|c|}
\hline Representative of the Genus Bacillus & Research Material & References \\
\hline Bacillus megaterium & Poly (ethylene terephthalate) & [28] \\
\hline Bacillus lentus & Polyethylene & [42] \\
\hline Bacillus mycoides & Polyethylene & {$[29,30,35,42,44]$} \\
\hline \multirow{2}{*}{ Bacillus pumilus } & Polyethylene & {$[29,30]$} \\
\hline & Polyurethane & [69] \\
\hline Bacillus safensis & Polyethylene & [45] \\
\hline \multirow{3}{*}{ Bacillus sp. } & Polyethylene & [46-51] \\
\hline & Polystyrene & [57-59] \\
\hline & Poly (vinyl chloride) & [51] \\
\hline Bacillus sphericus & Polyethylene & {$[29,30]$} \\
\hline \multirow{5}{*}{ Bacillus subtilis } & Polyethylene & [42-44] \\
\hline & Polyethylene oxide hydrogel & [43] \\
\hline & Polystyrene & [61] \\
\hline & Poly (ethylene terephthalate) & {$[64,66]$} \\
\hline & Polyurethane & {$[70-72]$} \\
\hline \multirow{2}{*}{ Bacillus thuringiensis } & Polyethylene & {$[29,30]$} \\
\hline & Polypropylene & [54] \\
\hline $\begin{array}{l}\text { Bacillus cereus + Bacillus megaterium + } \\
\text { Bacillus subtilis }\end{array}$ & Polyethylene & [48] \\
\hline Bacillus flexus + Bacillus subtilis & Polypropylene & [52] \\
\hline Bacillus mycoides + Penicillium frequentans & Polyethylene & [35] \\
\hline
\end{tabular}




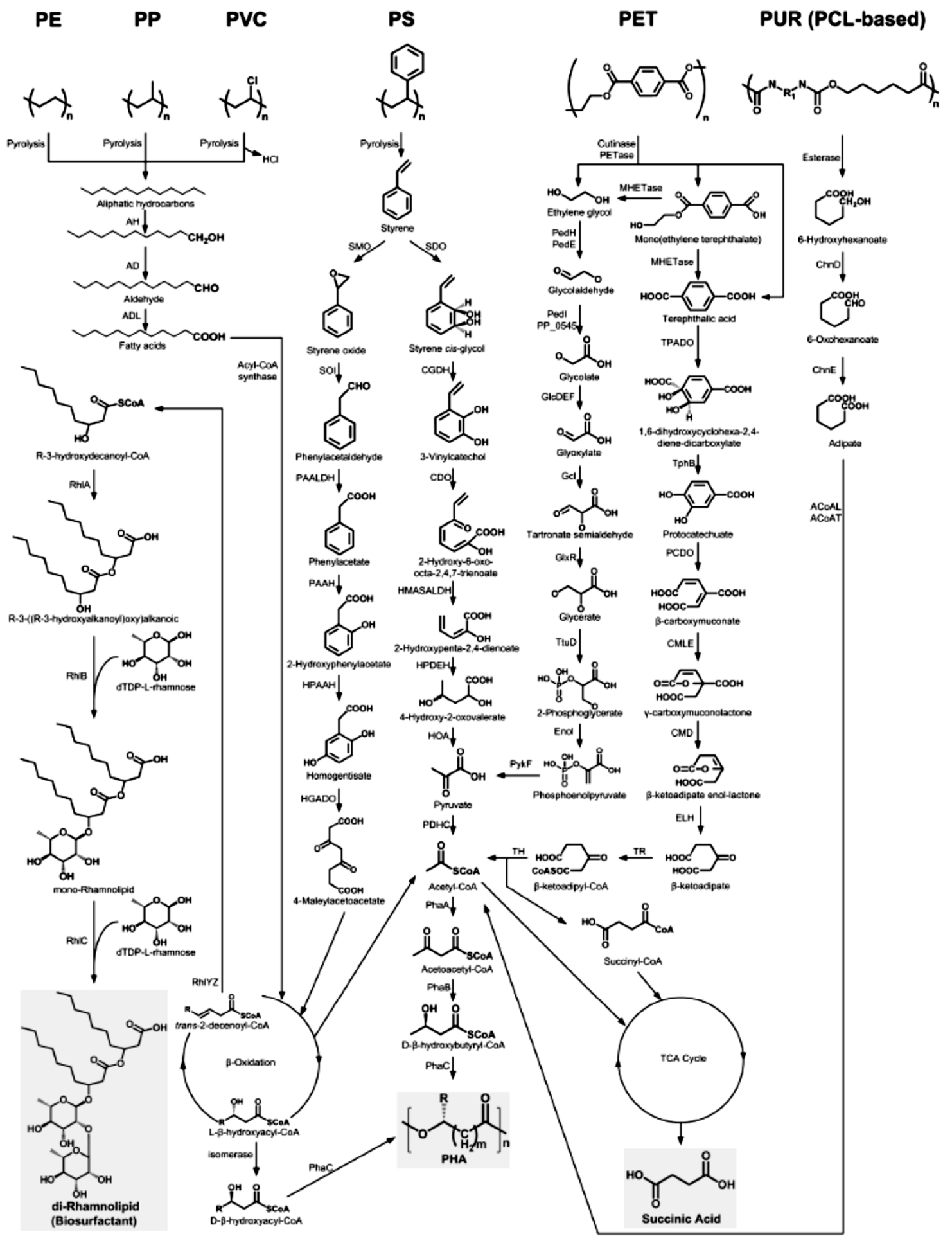

Figure 4. The metabolic pathways of depolymerization products of six kinds of plastics [74]. Plastics: PE, polyethylene; PS, polystyrene; PP, polypropylene; PVC, polyvinyl chloride; PUR, polyurethane; PCL, polycaprolactone diol; PET, polyethylene terephthalate. Enzymes: AH, alkane hydroxylase; AD, alcohol dehydrogenase; ALD, aldehyde dehydrogenase; RhlYZ, R-specific enoyl-CoA hydratase; RhlA, HAA synthetase; RhlB, rhamnosyltransferase 1; RhlC, rhamnosyltransferase 2; SMO, styrene monooxgenase; SOI styrene oxide isomerase; PAALDH, phenacetaldehyde dehydrogenase; PAAH, phenylacetate hydroxylase; HPAAH, 2-hydroxyphenylacetate hydroxylase; HGADO, homogentisate 1,2-dioxygenase; SDO, styrene dioxygenase; CGDH, cis-glycol dehydrogenase; CDO, catechol 2,3-dioxygenase; HMASALDH, 2-hydroxymuconic acid semialdehyde hydrolase; HPDEH, 2-hydroxypenta-2,4-dienoate hydratase; HOA, 4-hydroxy-2-oxovalerate aldolase; PDHC, pyruvate dehydrogenase complex; PhaA, b-ketothiolase; PhaB acetoacetyl-CoA reductase; PhaC, PHA synthase; PedH, quinoprotein alcohol dehydrogenase; PedE, quinoprotein alcohol dehydrogenase; PedI, aldehyde dehydrogenase family pr- 
otein; PP_0545, aldehyde dehydrogenase family protein; GlcDEF, glycolate oxidase; Gcl glyoxylate carboligase; GlxR, tartronate semialdehyde reductase; TtuD, hydroxypyruvate reductase; PykF, pyruvate kinase; TPADO, TPA dioxygenase; TphB, 1,2-dihydroxy-3,5-cyclohexadiene-1,4-dicarboxylate dehydrogenase; PCDO, protocatechuate 3,4-dioxygenase; CMLE, b-carboxy-cis,cis-muconate lactonizing enzyme; CMD, b-carboxymuconolactone decarboxylase; ELH, enollactone hydrolase; TR, b-ketoadipate:succinyl-CoA transferase; TH, b-ketoadipyl-CoA thiolase; ChnD, 6-hydroxycaproate dehydrogenase; ChnE, 6-oxohexanoic dehydrogenase; ACoAL, adipate-CoA ligase; ACoAT, acetyl-CoA C-acyltransferase [74].

\section{The Application of Bacteria of the Genus Bacillus to Materials' Biodamage Control}

It should be noted that today the question of the application of biological control for protection against corrosion damage is debatable, as none of the methods for corrosion inhibition by microorganisms found to be successful reached the practical application stage [7]. However, there are noteworthy publications on the possibility of using bacteria of the genus Bacillus to control the biodamage of materials.

The inhibition of corrosion by bacteria is often accomplished by: (1) a decrease in the corrosive action of the medium in restricted parts of the metal-bulk solution interface, for instance, by neutralizing the acidity of the medium; (2) the formation of protective films on the metal surface or providing new protective films, in particular through the production of EPS with metal-binding abilities; and (3) decreasing the cathodic reaction due to the consumption of a cathodic electron acceptor by microbes [6].

In addition, the biocontrol properties of some microorganisms are determined by their high antibacterial properties associated with the formation of antimicrobial compounds [75] and antibiofilm-forming properties due to their ability to affect the quorum sensing system [11]. Such microorganisms include members of the genus Bacillus. Thus, a number of studies have proved that corrosion results from the formation of biofilms, while Bacillus sp. [24,76], B. thuringiensis strain SN8 [21], B. cereus [77], B. licheniformis (including genetically modified ones) [78], B. subtilis [79-81], B. firmus strain H2O-1 [82,83] and B. brevis [79] are responsible for producing antimicrobial compounds.

In particular, in conditions of artificial seawater in the presence of a protective biofilm of B. subtilis strain WB600, passivation of Al 2024 was recorded. The addition of antibiotics led to the death of bacteria in the biofilm, which was reflected in the impedance spectra. Adding antibiotics to sterile artificial seawater had no effect on corrosion processes [81].

The inhibiting effect of B. thuringiensis strain SN8 on steel is shown in the publication by Bano et al. [21]. B. thuringiensis strain SN8 inhibited the MIC of materials in soil conditions over a period of 150 days. The corrosion-preventing properties of the $B$. thuringiensis strain SN8 dissipated after this period. It stands to reason that corrosioninhibiting/protective properties of biological agents must be verified in term of the maximum time frame for their effectiveness [84].

The inhibitory effect of a biofilm formed by B. cereus was shown by Aïmeur et al. [77].

Ornek et al. evaluated the effect of aluminum-chelating anionic peptides, which release biofilms of natural and genetically modified Bacillus on the pitting of aluminum alloy in continuous reactors [78]. The corrosion rate of aluminum alloy 2024 was reduced by $90 \%$ due to $\gamma$-polyglutamate-forming biofilm of B. licheniformis. Meanwhile, one of the peptides that secreted the genetically engineered biofilm of B. subtilis only slightly reduced the pitting compared to the biofilm on the control material, which already significantly reduces the corrosion of aluminum compared to the sterile control one.

From thermophilic B. licheniformis on a steel substrate, the bacterial biofilm and the nature of its extracellular polymeric substances have been probed chemically and electrochemically for their influences on metal dissolution within an incubation period [85]. Corrosion inhibition in the presence of varying concentrations (in CFU $/ \mathrm{ml}$ ) of these bacteria in biotic inoculate systems is explained in terms of corrosion resistance and biofilm capacity. Steel's corrosion rate is reduced significantly in saline culture medium within the range of concentrations of bacteria under study compared with the sterile control. This is attributed to the adhesion of relatively compact and dense "beneficial" biofilm as well 
as the secretion of corrosion-inhibiting substances from the bacterial biofilm as revealed during surface analysis [85].

Jayaraman et al. [79] found that biofilms of genetically engineered B. subtilis secreting the antibiotics indolicidin, bactenecin and probacterin are able to inhibit the growth of SRB that cause corrosion (D. vulgaris and D. gigas) and significantly reduce corrosion in a continuous culture.

The gramicidin $S$ peptide, which naturally produced the biofilm-forming strain of $B$. brevis, also inhibited the colonization of SRB and reduced the corrosion of the steel [86]. It should be noted that antibiotics, such as ampicillin, inhibited only the growth of SRB when added prior to the colonization of SRB. At the same time, the associative culture of $B$. brevis (producing S-gramicidin) with SRB completely blocked the growth of the latter.

Bacillus sp. strain H2O-1, isolated from the connate water of a Brazilian reservoir, produces an antimicrobial substance (denoted as AMS H2O-1) that is active against sulfatereducing bacteria, which are the major bacterial group responsible for biogenic souring and biocorrosion in petroleum reservoirs. AMS H2O-1 is a mixture of four surfactin-like homologues, and its biocidal activity and surfactant properties suggest that this compound may be a good candidate for sulfate-reducing bacterial control. Thus, it is a potential alternative to the chemical biocides or surface-coating agents currently used to prevent SRB growth in petroleum industries [82].

A new antimicrobial substance is being developed by using biosurfactant produced by indigenous oil reservoir Bacillus sp. to prevent and eradicate biofilm [76]. The biosurfactant is able to inhibit Pseudomonas sp. strain 1 and Pseudomonas sp. strain 2 attachment to carbon steel ST37 surfaces and also able to eradicate preformed biofilm on steel surfaces. This study also showed the reduction of corrosion rate in carbon steel ST37 as a result of material treatment with biosurfactants. The authors suggest that the biosurfactant in this study could be a good candidate for a new anticorrosion agent [76].

The effects of bacteria of the genus Bacillus depend not only on the formation of antimicrobial compounds and protective biofilm, but also on the type of damaged material. In particular, Juzeliunas and co-authors found that B. mycoides accelerates zinc corrosion, inhibits aluminum corrosion and does not affect mild steel [23].

Bacillus sp. strain ПКИ-12Лis considered to be a promising biological agent for the creation of a biological product for the protection of polymeric composite materials from biological damage due to its fungicidal activity [87].

The synthesis of extracellular molecules such as biosurfactants or proteins should have major influence on bacterial adhesion. These molecules may be adsorbed on surfaces and modify their energy characteristics. Under these conditions, adhesion rates are not dependent upon the initial characteristics of the substrate but on those of fouled surfaces [88].

Lipopeptides produced by B. subtilis (surfactin, iturin and fengycin) are able to modify the surface hydrophobicity of stainless steel and Teflon and, consequently, influence microbial adhesion to their surfaces [27]. The authors showed that these effects depend on the lipopeptide type, the concentration and the substratum. Thus, iturin A had no effect in relation to stainless steel; surfactin and fengycin increased the hydrophobicity of steel. The bioconditioning of surfaces using microbial surfactants has been suggested as a new strategy for reducing adhesion of bacteria to surfaces [27].

Among the representatives of the genus Bacillus as controlling agents of biodamage, the bacterium $B$. velezensis deserves attention $[11,75]$. It should be noted that the current heterotypic synonyms of $B$. velezensis are $B$. amyloliquefaciens subsp. plantarum, $B$. methylotrophicus, "B. oryzicola", and B. methylotrophicus subsp. plantarum $[89,90]$.

In the article of Wang et al. [91], high activity against marine fouling by proteases isolated from B. velezensis strain SM-1 was noted. This may be the basis of the modern eco-friendly approach to creating materials against fouling. Khan et al. isolated the bacterium $B$. methylotrophicus WY with the ability to quench the quorum, which can be used to control membrane biofouling [11]. In particular, it was discovered that this strain 
has significant influence on the degradation of acylhomoserinlactone (AHSL)—a kind of signaling molecule required for the development of biofilm. The inhibitory activity of B. velezensis strain K68 against the biofilm of Streptococcus mutans on polystyrene was studied [92]. Bacillus sp. strain H2O-1 (with 99.8 and 99.5\% similarity of the $16 \mathrm{~S}$ rRNA gene sequence between it and the type strains of B. amyloliquefaciens and B. methylotrophicus, respectively) produced an antimicrobial substance that was active against sulfate-reducing bacteria [82].

High concentrations of the catalase and peroxidase enzymes produced by some strains of Bacillus sp. can inhibit corrosion [25]. However, the exact mechanism and enzymatic role are unknown. Further research targets the potential role of these enzymes [25].

\section{Siderophores of Bacteria in Corrosion Damage of Materials}

It is known that the corrosion process takes place in a biofilm formed with the participation of a microbial community, the main participants of which are SRB $[1,7,93]$. From the end of the 20th to the beginning of the 21st century, the prospect of preventing corrosion damage to materials by forming protective aerobic bacterial biofilms capable of producing siderophores was discussed [94]. Siderophores are low molecular weight compounds that chelate Fe (III) ions, convert insoluble Fe (III) to the bioavailable form of Fe (II) and are synthesized by some bacteria, fungi and plants with iron ion deficiency in the medium [95,96]. Kostakioti et al. note [97] that chelating agents inhibit and/or disrupt the formation of the biofilm at stages 2 and 3 of biofilm formation, the formation of microcolonies and the maturation of the biofilm, respectively [97]. Siderophores are able to prevent the formation of biofilms of SRB on surfaces [98]. We studied the formation of SRB biofilms on the surface of polypropylene, which is used in the construction of pipelines $[99,100]$ and PET under the influence of bacillibactin-producing strains of $B$. velezensis [98]. Thus, a significant positive effect of supernatant ( $7 \%$ by volume) of $B$. velezensis strains NUChC $C 1$ and NUChC $C 2 b$ cultures in meat-peptone broth (MPB) on the biofilm formation of sulfate-reducing bacteria of Desulfovibrio oryzae (D. oryzae) strain NUChC SRB1 on the surface of polypropylene was noted [101]. Due to the production of B. velezensis strains NUChC C1 and NUChC C2b siderophore bacillibactin [98], it is possible that under these conditions the concentration of Fe (III) ions in the medium increases, which increases the intensity of sulfate-reducing bacteria biofilm formation. According to Donlan [102], with increasing concentration of Fe (III), there is a better adhesion of bacterial cells to the surface, which occurs by reducing the repulsive forces between negatively charged bacterial cells and surfaces. The influence of ions of iron on SRB-influenced corrosion is a complex phenomenon: (1) the hydrogenase of SRB is regulated by $\mathrm{Fe}^{2+}$ availability; (2) high levels of soluble iron prevent the formation of FeS protective layers [93].

However, with respect to $D$. oryzae strain NUChC SRB2 under these conditions, a slight significant inhibition of the intensity of biofilm formation was observed. Additionally, a significant decrease ( 2 times) in the intensity of sulfate-reducing bacterium $D$. oryzae strain NUChC SRB1 biofilm formation was registered on the surface of PET with a content in the medium of $22 \% \mathrm{MPB}$ supernatant cultures of B. velezensis strains NUChC C1 and $\mathrm{NUChC} \mathrm{C2b} \mathrm{[98].} \mathrm{It} \mathrm{is} \mathrm{possible} \mathrm{to} \mathrm{assume} \mathrm{two} \mathrm{mechanisms} \mathrm{lowering} \mathrm{the} \mathrm{intensity} \mathrm{of} \mathrm{biofilm}$ formation of SRB at a high concentration of bacillibactin. The first one involves bacillibactin as a siderophore chelator. When present in a high concentration in the supernatant, it apparently binds iron, reducing its amount, thus resulting in impaired bacterial biofilm formation. It is known that catecholate siderophores, which include bacillibactin, show a high affinity for iron [103-105]. The ability of chelators to inhibit the formation of biofilms is discussed in [97], while their capability of lowering the intensity of biofilm formation by reducing the concentration of iron is addressed in [106]. Under iron-deficient growth conditions, the microbial surface hydrophobicity decreases, which alters the surface protein composition and limits biofilm formation [107]. In general, the corrosion process involving bacteria of the genus Bacillus is associated with iron homeostasis as the increase in the content of ions of this metal stimulates the formation of biofilms (protective or 
corrosive, determined by the metabolism of a particular species and strain of bacteria). The second mechanism may be the modification of the surface properties of the material by bacillibactin from the supernatant in a high concentration, which affects the ability of SRB to form biofilms on it. In particular, it is indicated that catecholate siderophores constitute a class of natural products useful for surface modification [108]. We can assume that high concentrations of artificially introduced siderophore chelator will inhibit the corrosion process due to inhibition of biofilm formation and/or modification of the material surface properties. The validity of the proposed mechanisms has yet to be investigated.

Siderophores are environmentally unobjectionable compounds with high corrosion inhibitory properties on steel [109-112], promoting passivation of metals [113-115]. They are referred to as green corrosion inhibitors along with macromolecules, bacteria, alkaloids and polyphenols [89]. Bacillus sp. strain AS7 is a producer of siderophore desferrioxamine $B$ [113]. The obtained siderophore worked as a green smart corrosion inhibitor of SAE1010 carbon steel at a minimal concentration of 75 ppm [88]. Based on the obtained data, we believe that the supernatant from cultures of bacillibactin-producing strains of $B$. velezensis strains NUChC C1 and NUChC C2b can be used as a smart green inhibitor to prevent microbe-induced corrosion by inhibiting the development of SRB biofilms. A further prospect is the study of microbiologically influenced corrosion of steel under the influence of SRB and the presence of supernatant from these cultures of $B$. velezensis.

The generalization of the protective activity of bacteria of the genus Bacillus in relation to some biodegradation materials is presented in Tables 6 and 7.

Table 6. Protective activity of bacteria of the genus Bacillus in relation to material biodegradation.

\begin{tabular}{|c|c|c|}
\hline Representative of the Genus Bacillus & Research Material & References \\
\hline Bacillus brevis & 304 stainless steel & [79] \\
\hline Bacillus cereus & Carbon steel & {$[77]$} \\
\hline Bacillus firmus & $\begin{array}{l}\text { Stainless steel AISI 304, stainless steel AISI 430, } \\
\text { carbon steel, galvanized steel, polystyrene }\end{array}$ & {$[82,83]$} \\
\hline \multirow{2}{*}{ Bacillus licheniformis/paralicheniformis } & Al 2024 & [78] \\
\hline & Stainless steel $316 \mathrm{~L}$ & [85] \\
\hline \multirow{3}{*}{ Bacillus sp. } & Carbon steel ST37 & [76] \\
\hline & Polymer composite materials & [87] \\
\hline & Carbon steel SAE-1010 & [113] \\
\hline \multirow{4}{*}{ Bacillus subtilis } & 304 stainless steel & [79] \\
\hline & Stainless steel & [80] \\
\hline & Al 2024 & [81] \\
\hline & Stainless steel & [27] \\
\hline Bacillus thuringiensis & Mild steel & [21] \\
\hline \multirow{4}{*}{ Bacillus velezensis } & Membrane filtration system & [11] \\
\hline & Organisms of marine fouling & [91] \\
\hline & Polystyrene & [92] \\
\hline & Poly (ethylene terephthalate) & [98] \\
\hline
\end{tabular}


Table 7. The compounds produced by bacteria of the genus Bacillus, which are important for the control of material biodamage.

\begin{tabular}{|c|c|c|}
\hline Representative of the Genus Bacillus & Compound & References \\
\hline Bacillus brevis & Gramicidin S peptide, ampicillin & [86] \\
\hline \multirow{2}{*}{ Bacillus licheniformis/paralicheniformis } & Chelating anionic peptides & [78] \\
\hline & $\gamma$-polyglutamate & [78] \\
\hline \multirow{5}{*}{ Bacillus sp. } & Surfactin-like homologues & [82] \\
\hline & Biosurfactant & [76] \\
\hline & Antifungal compounds & [87] \\
\hline & Siderophore desferroxamine B & [113] \\
\hline & Catalase and peroxidase (high concentrations) & [25] \\
\hline Bacillus subtilis & Surfactin, iturin, fengycin & [27] \\
\hline Bacillus subtilis (genetically engineered) & Indolicidin, bactenecin, probacterin & {$[79]$} \\
\hline \multirow{2}{*}{ Bacillus velezensis } & Siderophore bacillibactin & [98] \\
\hline & Compounds with the property of destroying AHSL & [11] \\
\hline
\end{tabular}

\section{Progress, Challenges and Future Direction for This Work}

The involvement of bacteria of the genus Bacillus in biodamage/biodegradation of materials has been actively studied in recent years. Today, it is known that they are either corrosively active participants in microbiologically influenced corrosion, or act as biological control agents, protecting materials from damage. The functions of bacteria of the genus Bacillus in MIC processes are associated with the production of corrosive metabolites and the impact of certain bioelectrochemical mechanisms. Among the compounds produced by bacteria of the genus Bacillus important for the control of biodamage are antibiotics, lipopeptides, biosurfactants, poly- $\gamma$-glutamic acid and siderophores $[76,78,79,86,87,98,113]$. Such compounds have either an antimicrobial effect or are able to modify the hydrophobicity of material surfaces, thereby affecting the adhesion of bacterial cells on it, which is reflected in the formation of the biofilm. These compounds are environmentally unobjectionable, and therefore are promising as the green corrosion inhibitors. As a prospect of research in this field, we see the study of siderophores as green inhibitors of microbe-induced corrosion, in particular bacillibactin, because these compounds combine antibiofilm-forming properties with high inhibitory properties.

\section{Conclusions}

Bacillus are representatives of microorganisms involved in the processes of microbiologically influenced corrosion of metals and alloys and biodegradation of synthetic plastics in both mono- and associative cultures. Their role depends on the species, strain of the microorganism, the production of antimicrobial substances, the biofilm formation and the type of damaged material. On the one hand, these bacteria can be agents of biodamage, and on the other hand they can inhibit biodamage. The involvement of bacteria of the genus Bacillus in MIC processes is associated with the production of corrosive metabolites and the impact of bioelectrochemical mechanisms. Lipopeptides produced by B. subtilis (surfactin, iturin and fengycin) are able to modify the surface hydrophobicity, to influence microbial adhesion to the surfaces. It is possible that siderophore chelators (bacillibactin) can also modify surface hydrophobicity and at high concentrations are able to inhibit bacterial biofilm formation, thus slowing down the degradation of materials. Therefore, the process of microbiologically influenced corrosion under the influence of bacteria, the genus Bacillus, producing siderophores, requires further investigations. Thus, the generalized scheme of mechanisms of participation of bacteria of the genus Bacillus in the processes of biodamage of some metals and plastics can be represented as follows (Figure 5). 


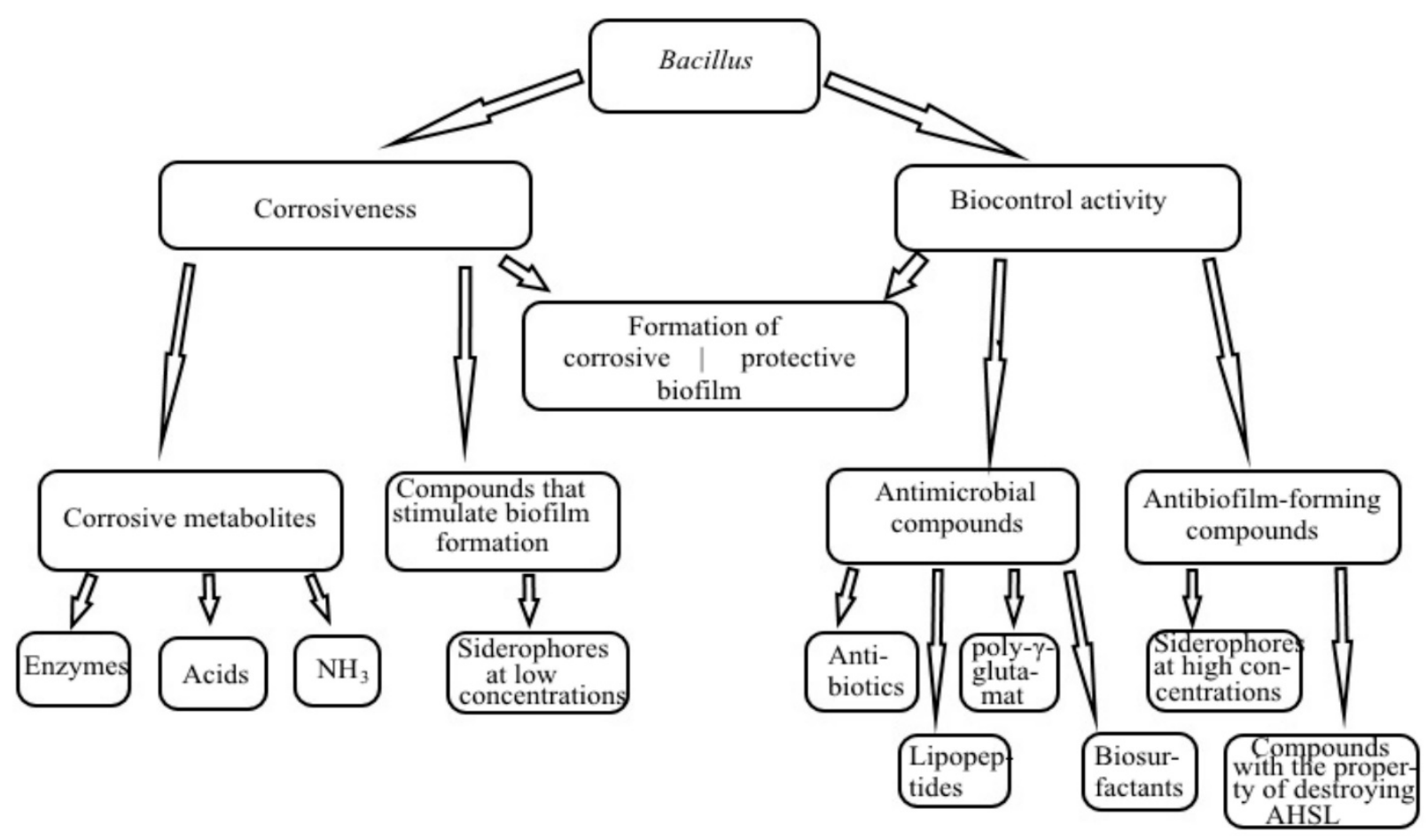

Figure 5. Mechanisms of participation of bacteria of the genus Bacillus in biodamage of some metals and plastics.

Author Contributions: Writing-original draft preparation, N.T. and L.Z.; writing-review and editing, N.T. and L.Z.; visualization, N.T.; supervision, N.T. Both authors have read and agreed to the published version of the manuscript.

Funding: This research received no external funding.

Institutional Review Board Statement: Not applicable.

Informed Consent Statement: Not applicable.

Data Availability Statement: Not applicable.

Conflicts of Interest: The authors declare no conflict of interest.

\section{References}

1. Andreyuk, K.; Kozlova, I.; Kopteva, Z.; Pilyashenko-Novokhatny, A.; Zanina, V.; Purish, L. Mikrobna Koroziia Pidzemnykh Sporud; Naukova Dumka Publishing House: Kyiv, Ukraine, 2005; 258p. (In Ukrainian)

2. Tregubova, N.V.; Kochkarov, R.H.; Morgunova, A.V.; Drizhd, N.A.; Dinaev, E.K. Biopovrezhdeniya Produktov; Publishing and Information Center "Fabula": Stavropol, Russia, 2019; 100p. (In Russian)

3. Netrusov, A.I.; Bonch-Osmolovskaya, E.A.; Gorlenko, V.M.; Ivanov, M.V.; Karavajko, G.I.; Kozhevin, P.A.; Kolotilova, N.N.; Kotova, I.B.; Maksimov, V.N.; Nozhevnikova, A.N.; et al. Ekologiya Mikroorganizmov; Netrusov, A.I., Ed.; Academia Publishing Center: Moscow, Russia, 2004; 272p. (In Russian)

4. Scarascia, G.; Wang, T.; Hong, P.-Y. Quorum sensing and the use of quorum quenchers as natural biocides to inhibit sulfatereducing bacteria. Antibiotics 2016, 5, 39. [CrossRef]

5. Smykun, N.V. Rozvytok koroziino-nebezpechnoi mikroflory gruntu pid vplyvom deiakykh pestytsydiv. Mikrobiol. Z. 2008, 70, 74-87. (In Ukrainian) [PubMed]

6. Lin, J.; Ballim, R. Biocorrosion control: Current strategies and promising alternatives. Afr. J. Biotechnol. 2012, 11, 15736-15747. [CrossRef]

7. Little, B.J.; Blackwood, D.J.; Hinks, J.; Lauro, F.M.; Marsili, E.; Okamoto, A.; Rice, S.A.; Wade, S.A.; Flemming, H.-C. Microbially influenced corrosion-Any progress? Corros. Sci. 2020, 170, 108641. [CrossRef]

8. Wang, Y.S.; Liu, L.; Fu, Q.; Sun, J.; An, Z.Y.; Ding, R.; Li, Y.; Zhao, X.D. Effect of Bacillus subtilis on corrosion behavior of $10 \mathrm{MnNiCrCu}$ steel in marine environment. Sci. Rep. 2020, 10, 5744. [CrossRef] [PubMed]

9. Shtil'man, M.I. Biodegradaciya polimerov. SibFU J. Biol. 2015, 2, 113-130. (In Russian)

10. Caulier, S.; Nannan, C.; Gillis, A.; Licciardi, F.; Bragard, C.; Mahillon, J. Overview of the Antimicrobial Compounds Produced by Members of the Bacillus subtilis Group. Front. Microbiol. 2019, 10, 302. [CrossRef] 
11. Khan, R.; Shen, F.; Khan, K.; Liu, L.X.; Wu, H.H.; Luo, J.Q.; Wan, Y.H. Biofouling control in membrane filtration system by newly isolated novel quorum quenching bacterium, Bacillus methylotrophicus sp. WY. RSC Adv. 2016, 6, 28895-28903. [CrossRef]

12. Blackwood, D.J. An Electrochemist Perspective of Microbiologically Influenced Corrosion. Corros. Mater. Degrad. 2018, 1, 5. [CrossRef]

13. Moura, M.C.; Pontual, E.V.; Paiva, P.M.G.; Coelho, L.C.B.B. An Outline to Corrosive Bacteria. In Microbial Pathogens and Strategies for Combating Them: Science, Technology and Education; Méndez-Vilas, A., Ed.; Formatex Research Center: Badajoz, Spain, 2013; Volume 1, pp. 11-22.

14. Nuňez, M. Prevention of Metal Corrosion: New Research; Nova Science Publishers, Inc.: New York, NY, USA, 2007; 313p.

15. Li, X.; Xiao, H.; Zhang, W.; Li, Y.; Tang, X.; Duan, J.; Yang, Z.; Wang, J.; Guan, F.; Ding, G. Analysis of cultivable aerobic bacterial community composition and screening for facultative sulfate-reducing bacteria in marine corrosive steel. J. Ocean. Limnol. 2019, 37, 600-614. [CrossRef]

16. Tkachuk, N.V.; Zelena, L.B.; Parminska, V.S.; Yanchenko, V.O.; Demchenko, A.M. Identyfikatsiia heterotrofnykh bakterii ferosfery gruntu ta yikh chutlyvist do pestytsydu linuron. Mikrobiol. Z. 2017, 79, 75-87. (In Ukrainian) [CrossRef]

17. Rajasekar, A.; Ting, Y.-P. Microbial Corrosion of Aluminum 2024 Aeronautical Alloy by Hydrocarbon Degrading Bacteria Bacillus cereus ACE4 and Serratia marcescens ACE2. Ind. Eng. Chem. Res. 2010, 49, 6054-6061. [CrossRef]

18. Bragadeeswaran, S.; Jeevapriya, R.; Prabhu, K.; Rani, S.S.; Priyadharsini, S.; Balasubramanian, T. Exopolysaccharide production by Bacillus cereus GU812900, a fouling marine bacterium. Afr. J. Microbiol. Res. 2011, 5, 4124-4132. [CrossRef]

19. Xu, D.; Li, Y.; Song, F.; Gu, T. Laboratory investigation of microbiologically influenced corrosion of C1018 carbon steel by nitrate reducing bacterium Bacillus licheniformis. Corros. Sci. 2013, 77, 385-390. [CrossRef]

20. Wan, H.; Song, D.; Zhang, D.; Du, C.; Xu, D.; Liu, Z.; Ding, D.; Li, X. Corrosion effect of Bacillus cereus on X80 pipeline steel in a Beijing soil environment. Bioelectrochemistry 2018, 121, 18-26. [CrossRef]

21. Bano, A.S.; Qazi, J.I. Soil buried mild steel corrosion by Bacillus cereus-SNB4 and its inhibition by Bacillus thuringiensis-SN8. Pak. J. Zool. 2011, 43, 555-562.

22. Santana, J.J.; Santana, F.J.; Gonzảlez, J.E.; Souto, R.M.; Gonzảlez, S.; Morales, J. Electrochemical analysis of the microbiologically influenced corrosion of AISI 304 stainless steel by sulphate reducing bacteria associated with Bacillus cereus. Int. J. Electrochem. Sci. 2012, 7, 711-724.

23. Juzeliunas, E.; Ramanauskas, R.; Lugauskas, A.; Leinartas, K.; Samulevicene, M.; Sudavicius, A. Influence of wild strain Bacillus mycoides on metals: From corrosion acceleration to environmentally friendly protection. Electrochim. Acta 2006, 51, 6085-6090. [CrossRef]

24. Du, J.; Li, S.; Liu, J.; Yu, M. Corrosion behavior of steel Q235 co-influenced by Thiobacillus thiooxidans and Bacillus. J. Beijing Univ. Aeronaut. Astronaut. 2014, 40, 31-38.

25. Karn, S.K.; Fang, G.; Duan, J. Bacillus sp. acting as dual role for corrosion induction and corrosion inhibition with carbon steel (CS). Front. Microbiol. 2017, 24, 2038. [CrossRef]

26. Mora, M.; Wink, L.; Kögler, I.; Mahnert, A.; Rettberg, P.; Schwendner, P.; Demets, R.; Cockell, C.; Alekhova, T.; Klingl, A.; et al. The International Space Station selects for microorganisms adapted to the extreme environment, but does not induce genomic and physiological changes relevant for human health. BioRxiv 2019, 533752, 1-44. [CrossRef]

27. Shakerifard, P.; Gancel, F.; Jacques, P.; Faille, C. Effect of different Bacillus subtilis lipopeptides on surface hydrophobicity and adhesion of Bacillus cereus 98/4 spores to stainless steel and Teflon. Biofouling 2009, 25, 533-541. [CrossRef] [PubMed]

28. Hiraga, K.; Taniguchi, I.; Yoshida, S.; Kimura, Y.; Oda, K. Biodegradation of waste PET: A sustainable solution for dealing with plastic pollution. EMBO Rep. 2019, 20, e49365. [CrossRef] [PubMed]

29. Restrepo-Flórez, J.-M.; Bassi, A.; Thompson, M.R. Microbial degradation and deterioration of polyethylene-A review. Int. Biodeter. Biodegr. 2014, 88, 83-90. [CrossRef]

30. Ghatge, S.; Yang, Y.; Jae-Hyung Ahn, J.-H.; Hur, H.-G. Biodegradation of polyethylene: A brief review. Appl. Biol. Chem. 2020, 63, 27. [CrossRef]

31. Hakkarainen, M.; Albertsson, A. Environmental degradation of polyethylene. Adv. Polym. Sci. 2004, 169, $177 . e 199$.

32. Novotný, Č.; Malachova, K.; Adamusc, G.; Kwiecień, M.; Lotti, N.; Soccio, M.; Verney, V.; Fava, F. Deterioration of irradiation/hightemperature pretreated, linear low-density polyethylene (LLDPE) by Bacillus amyloliquefaciens. Int. Biodeterior. Biodegrad. 2018, 132, 259-267. [CrossRef]

33. Leja, K.; Lewandowicz, G. Polymer Biodegradation and Biodegradable Polymers-A Review. Pol. J. Environ. Stud. 2010, 19, 255-266.

34. Van Beilen, J.B.; Li, Z.; Duetz, W.A.; Smits, T.H.M.; Witholt, B. Diversity of Alkane Hydroxylase Systems in the Environment. Oil Gas Sci. Technol.-Rev. IFP 2003, 58, 427-440. [CrossRef]

35. Seneviratne, G.; Tennkoon, N.S.; Weerasekara, M.L.M.A.W.; Nandasena, K.A. Polyethylene biodegradation by a developed Penicillium-Bacillus biofilm. Curr. Sci. 2006, 90, 20-21.

36. Montazer, Z.; Habibi Najafi, M.B.; Levin, D.B. Challenges with Verifying Microbial Degradation of Polyethylene. Polymers 2020, 12, 123. [CrossRef]

37. Das, M.P.; Kumar, S. An approach to low-density polyethylene biodegradation by Bacillus amyloliquefaciens. 3 Biotech 2015, 5, 81-86. [CrossRef] 
38. Wasserbauer, R.; Beranova, M.; Vancurova, D.; Dolezel, B. Biodegradation of polyethylene foils by bacterial and liver homogenates. Biomaterials 1990, 11, 36-40. [CrossRef]

39. Sowmya, H.V.; Ramalingappa, M.K.; Thippeswamy, B. Biodegradation of polyethylene by Bacillus cereus. Adv. Polym. Sci. Technol.-Int. J. 2014, 4, 28-32.

40. Suresh, B.; Maruthamuthu, S.; Palanisamy, N.; Ragunathan, R.; Pandiyaraj, K.N.; Muralidharan, V.S. Investigation on biodegradability of polyethylene by Bacillus cereus strain Ma-Su isolated from compost soil. Int. Res. J. Microbiol. 2011, 2, $292-302$.

41. Muhonja, C.N.; Makonde, H.; Magoma, G.; Imbuga, M. Biodegradability of polyethylene by bacteria and fungi from Dandora dumpsite Nairobi-Kenya. PLoS ONE 2018, 13, e0198446. [CrossRef]

42. Abdullahi, M.; Saidu, B. Biodegradation of polythene and plastic using fadama soil amended with organic and inorganic fertilizer. Indian J. Sci. Res. 2013, 4, 17-24.

43. Vimala, P.P.; Mathew, L. Biodegradation of polyethylene using Bacillus subtilis. Proc. Technol. 2016, 24, 232-239. [CrossRef]

44. Ibiene, A.A.; Stanley, H.O.; Immanuel, O.M. Biodegradation of Polyethylene by Bacillus sp. Indigenous to the Niger Delta Mangrove Swamp. Nig. J. Biotech. 2013, 26, 68-79.

45. Waqas, M.; Haris, M.; Asim, N.; Islam, H.; Abdullah, A.; Khan, A.; Khattak, H.; Waqas, M.; Ali, S. Biodegradable potential of Bacillus amyloliquefaciens and Bacillus safensis using low density polyethylene thermoplastic (LDPE) substrate. Eur. J. Environ. Public Health 2021, 5, em0069.

46. Pinchuk, L.S.; Makarevich, A.V.; Vlasova, G.M.; Kravtsov, G.A.; Shapovalov, V.A. Electret-thermal analysis to assess biodegradation of polymer composites. Int. Biodeter. Biodegr. 2004, 54, 13-18. [CrossRef]

47. Sudhakar, M.; Doble, M.; Sriyutha Murthy, P.; Venkatesan, R. Marine microbe-mediated biodegradation of low- and high-density polyethylenes. Int. Biodeterior. Biodegrad. 2008, 61, 203-213. [CrossRef]

48. Abrusci, C.; Pablos, J.L.; Marín, I.; Espí, E.; Corrales, T.; Catalina, F. Comparative effect of metal stearates as pro-oxidant additives on bacterial biodegradation of thermal- and photo-degraded low density polyethylene mulching films. Int. Biodeterior. Biodegrad. 2013, 83, 25-32. [CrossRef]

49. Yang, J.; Yang, Y.; Wu, W.-M.; Zhao, J.; Jiang, L. Evidence of Polyethylene Biodegradation by Bacterial Strains from the Guts of Plastic-Eating Waxworms. Environ. Sci. Technol. 2014, 48, 13776-13784. [CrossRef] [PubMed]

50. Usha, R.; Sangeetha, T.; Palaniswamy, M. Screening of polyethylene degrading microorganisms from garbage soil. Libyan Agric. Res. Cent. J. Int. 2011, 2, 200-204.

51. Kumari, A.; Chaudhary, D.R.; Jha, B. Destabilization of polyethylene and polyvinylchloride structure by marine bacterial strain. Environ. Sci. Pollut. Res. 2019, 26, 1507-1516. [CrossRef] [PubMed]

52. Aravinthan, A.; Arkatkar, A.; Juwarkar, A.A.; Doble, M. Synergistic growth of Bacillus and Pseudomonas and its degradation potential on pretreated polypropylene. Prep. Biochem. Biotechnol. 2016, 46, 109-115. [CrossRef] [PubMed]

53. Auta, H.S.; Emenike, C.U.; Fauziah, S.H. Screening for Polypropylene Degradation Potential of Bacteria Isolated from Mangrove Ecosystems in Peninsular Malaysia. Int. J. Biosci. Biochem. Bioinform. 2017, 7, 245-251. [CrossRef]

54. Kimi, J.; Bhunia, H.; Reddy, M.S. Degradation of polypropylene-poly-L-lactide blends by Bacillus isolates: A microcosm and field evaluation. Bioremed. J. 2021, 1-15. [CrossRef]

55. Auta, H.S.; Emenike, C.U.; Fauziah, S.H. Screening of Bacillus strains isolated from mangrove ecosystems in Peninsular Malaysia for microplastic degradation. Environ. Pollut. 2017, 231, 1552-1559. [CrossRef]

56. Mohanan, N.; Montazer, Z.; Sharma, P.K.; Levin, D.B. Microbial and Enzymatic Degradation of Synthetic Plastics. Front. Microbiol. 2020, 11, 2837. [CrossRef]

57. Shimpi, N.; Mishra, S.; Kadam, M. Biodegradation of polystyrene (PS)-poly(lactic acid) (PLA) nanocomposites using Pseudomonas aeruginosa. Macromol. Res. 2012, 20, 181-187. [CrossRef]

58. Atiq, N.; Ahmed, S.; Ishtiaq Ali, M.; Andleeb, S.; Ahmad, B.; Robson, G. Isolation and identification of polystyrene biodegrading bacteria from soil. Afr. J. Microbiol. Res. 2010, 4, 1537-1541.

59. Mohan, A.J.; Sekhar, V.C.; Bhaskar, T.; Nampoothiri, K.M. Microbial assisted High Impact Polystyrene (HIPS) degradation. Bioresour. Technol. 2016, 213, 204-207. [CrossRef]

60. Meng, T.K.; Beng, D.Y.Y.; Mohd Kassim, A.S.; Razak, A.H.A.; Mohd Fauzi, N.A. Optimization of Polystyrene Biodegradation using Response Surface Methodology (RSM) Measured by Simple Colorimetric Method. Int. J. Eng. Technol. 2018, 7, 216-220. [CrossRef]

61. Asmita, A.; Shubhamsingh, T.; Tejashree, S. Isolation of plastic degrading micro-organisms from soil samples collected at various locations in Mumbai, India. Int. Res. J. Environ. Sci. 2015, 4, 77-85.

62. Ganesh Kumar, A.; Hinduja, M.; Sujitha, K.; Nivedha Rajan, N.; Dharani, G. Biodegradation of polystyrene by deep-sea Bacillus paralicheniformis G1 and genome analysis. Sci. Total Environ. 2021, 774, 145002. [CrossRef]

63. Lou, Y.; Ekaterina, P.; Yang, S.-S.; Lu, B.; Liu, B.; Ren, N.; Corvini, P.F.X.; Xing, D. Biodegradation of polyethylene and polystyrene by greater wax moth larvae (Galleria mellonella L.) and the effect of co-diet supplementation on the core gut microbiome. Environ. Sci. Technol. 2020, 54, 2821-2831. [CrossRef]

64. Dabrowska, G.B.; Janczak, K.; Richert, A. Combined use of Bacillus strains and Miscanthus for accelerating biodegradation of poly(lactic acid) and poly(ethylene terephthalate). PeerJ 2021, 9, e10957. [CrossRef]

65. Vague, M.; Chan, G.; Roberts, C.; Swartz, N.A.; Mellies, J. Pseudomonas isolates degrade and form biofilms on polyethylene terephthalate (PET) plastic. BioRxiv 2019, 647321. [CrossRef] 
66. Wei, R.; Zimmermann, W. Microbial enzymes for the recycling of recalcitrant petroleum-based plastics: How far are we? Microb. Biotechnol. 2017, 10, 1308-1322. [CrossRef]

67. Giacomucci, L.; Raddadi, N.; Soccio, M.; Lotti, N.; Fava, F. Polyvinyl chloride biodegradation by Pseudomonas citronellolis and Bacillus flexus. New Biotechnol. 2019, 52, 35-41. [CrossRef]

68. Howard, G.T. Polyurethane Biodegradation. In Microbial Degradation of Xenobiotics, Environmental Science and Engineering; Singh, S.N., Ed.; Springer: Berlin/Heidelberg, Germany, 2012; pp. 371-394. [CrossRef]

69. Tan, J.D.; Ohwada, T. Isolation and identification of microorganisms for polyurethane degradation. Ann. Trop. Res. 2019, 41, 57-66. [CrossRef]

70. Rowe, L.; Howard, G.T. Growth of Bacillus subtilis on polyurethane and the purification and characterization of a polyurethanaselipase enzyme. Int. Biodeter. Biodegr. 2002, 50, 33-40. [CrossRef]

71. Shah, Z.; Krumholz, L.; Aktas, D.F.; Hasan, F.; Khattak, M.; Shah, A.A. Degradation of polyester polyurethane by a newly isolated soil bacterium, Bacillus subtilis strain MZA-75. Biodegradation 2013, 24, 865-877. [CrossRef] [PubMed]

72. Nakkabi, A.; Sadiki, M.; Fahim, M.; Ittobane, N.; Ibnsouda Koraichi, S.; Barkai, H.; El abed, S. Biodegradation of Poly(ester urethane)s by Bacillus subtilis. Int. J. Environ. Res. 2015, 9, 157-162.

73. Mahajan, N.; Gupta, P. New Insights into the Microbial Degradation of Polyurethanes. RSC Adv. 2015, 5, 41839-41854. [CrossRef]

74. Ru, J.; Huo, Y.; Yang, Y. Microbial Degradation and Valorization of Plastic Wastes. Front. Microbiol. Rev. 2020, 11, 442. [CrossRef]

75. Chowdhury, S.P.; Hartmann, A.; Gao, X.W.; Borriss, R. Biocontrol mechanism by root-associated Bacillus amyloliquefaciens FZB42-A review. Front. Microbiol. 2015, 6, 780. [CrossRef]

76. Purwasena, I.A.; Astuti, D.I.; Fauziyyah, N.A.; Putri, D.A.S.; Sugai, Y. Inhibition of microbial influenced corrosion on carbon steel ST37 using biosurfactant produced by Bacillus sp. Mater. Res. Express. 2019, 6, 115405. [CrossRef]

77. Aïmeur, N.; Houali, K.; Hamadou, L.; Benbrahim, N.; Kadri, A. Influence of strain Bacillus cereus bacterium on corrosion behaviour of carbon steel in natural sea water. Corros. Eng. Sci. Technol. 2015, 50, 579-588. [CrossRef]

78. Ornek, D.; Jayaraman, A.; Syrett, B.C.; Hsu, C.H.; Mansfeld, F.B.; Wood, T.K. Pitting corrosion inhibition of aluminum 2024 by Bacillus biofilms secreting polyaspartate or g-polyglutamate. Appl. Microbiol. Biotechnol. 2002, 58, 651-657. [CrossRef] [PubMed]

79. Jayaraman, A.; Mansfeld, F.B.; Wood, T.K. Inhibiting sulfate-reducing bacteria in biofilms by expressing the antimicrobial peptides indolicidin and bactenecin. J. Ind. Microbiol. Biotechnol. 1999, 22, 167-175. [CrossRef]

80. Wadood, H.Z.; Rajasekar, A.; ·Ting, Y.-P.; Sabari, A.N. Role of Bacillus subtilis and Pseudomonas aeruginosa on Corrosion Behaviour of Stainless Steel. Arab. J. Sci. Eng. 2015, 40, 1825-1836. [CrossRef]

81. Zuo, R.; Kus, E.; Mansfeld, F.; Wood, T.K. The importance of live biofilms in corrosion protection. Corros. Sci. 2005, 47, 279-287. [CrossRef]

82. Korenblum, E.; de Araujo, L.V.; Guimarães, C.R.; de Souza, L.M.; Sassaki, G.; Abreu, F.; Nitschke, M.; Lins, U.; Freire, D.M.G.; Barreto-Bergter, E.; et al. Purification and characterization of a surfactin-like molecule produced by Bacillus sp. $\mathrm{H} 2 \mathrm{O}-1$ and its antagonistic effect against sulfate reducing bacteria. BMC Microbiol. 2012, 12, 252. [CrossRef]

83. Korenblum, E.; Sebastián, G.V.; Paiva, M.M.; Coutinho, C.M.L.M.; Magalhães, F.C.M.; Peyton, B.M.; Seldin, L. Action of antimicrobial substances produced by different oil reservoir Bacillus strains against biofilm formation. Appl. Microbiol. Biotechnol. 2008, 79, 97-103. [CrossRef]

84. Hussain, A.; Bano, S.S.; Qazi, J.I. Corrosion of Mild Steel Simulating Long Term Soil Burial Field Conditions Differing in Nutritional and Biotic Components. World Appl. Sci. J. 2013, 22, 985-990.

85. Eduok, U.; Khaled, M.; Khalil, A.; Suleiman, R.; El Ali, B. Probing the corrosion inhibiting role of thermophilic Bacillus licheniformis biofilm 1 on steel in a saline axenic culture. RSC Adv. 2016, 6, 18246-18256. [CrossRef]

86. Jayaraman, A.; Hallock, P.J.; Carson, R.M.; Lee, C.C.; Mansfeld, F.B.; Wood, T.K. Inhibiting sulfate-reducing bacteria in biofilms on steel with antimicrobial peptides generated in situ. Appl. Microbiol. Biot. 1999, 52, 267-275. [CrossRef] [PubMed]

87. Erofeevskaya, L.A.; Kychkin, A.K.; Kychkin, A.A. Prognozirovanie biodegradacii polimernyh kompozicionnyh materialov v klimaticheskih usloviyah Yakutii. Innovacii Invest. 2019, 6, 202-207. (In Russian)

88. Garry, P.; Vendeuvre, J.L.; Bellon-Fontaine, M.N. Surface properties and adhesion of Bacillus cereus and Bacillus subtilis to polyurethane-Influence of growth temperature. J. Disper. Sci. Technol. 1998, 19, 1175-1197. [CrossRef]

89. NCBI. Taxonomy Browser. Available online: https://www.ncbi.nlm.nih.gov/Taxonomy/Browser/wwwtax.cgi?mode=Info\&id= 492670\&lvl=3\&lin=f\&keep $=1 \&$ srchmode $=1$ \&unlock (accessed on 5 September 2019).

90. Dunlap, C.A.; Kim, S.-J.; Kwon, S.-W.; Rooney, A.P. Bacillus velezensis is not a later heterotypic synonym of Bacillus amyloliquefaciens; Bacillus methylotrophicus, Bacillus amyloliquefaciens subsp. plantarum and 'Bacillus oryzicola' are later heterotypic synonyms of Bacillus velezensis based on phylogenomics. Int. J. Syst. Evol. Microbiol. 2016, 66, 1212-1217. [CrossRef] [PubMed]

91. Wang, L.; Yu, L.; Lin, C. Extraction of protease produced by sea mud bacteria and evaluation of antifouling performance. J. Ocean Univ. China 2019, 18, 1139-1146. [CrossRef]

92. Yoo, Y.; Seo, D.-H.; Lee, H.; Cho, E.-S.; Song, N.-E.; Nam, T.G.; Nam, Y.-D.; Seo, M.-J. Inhibitory effect of Bacillus velezensis on biofilm formation by Streptococcus mutans. J. Biotechnol. 2019, 298, 57-63. [CrossRef]

93. Beech, I.B.; Gaylarde, C.C. Recent advances in the study of biocorrosion: An overview. Rev. Microbiol. 1999, 30, 117-190. [CrossRef]

94. Little, B.; Ray, R. A Perspective on Corrosion Inhibition by Biofilms. Corrosion 2002, 58, 424-428. [CrossRef] 
95. Saha, M.; Sarkar, S.; Sarkar, B.; Sharma, B.K.; Bhattacharjee, S.; Tribedi, P. Microbial siderophores and their potential applications: A review. Environ. Sci. Pollut. Res. 2015, 23, 3984-3999. [CrossRef]

96. Leonov, V.V.; Mironov, A.Y.; Anan'ina, I.V.; Rubal'skaya, E.E.; Sentyurova, L.G. Mikrobnye siderofory: Struktura, svojstva, funkcii. Astrakhan Med. J. 2016, 11, 24-37. (In Russian)

97. Kostakioti, M.; Hadjifrangiskou, M.; Hultgren, S.J. Bacterial biofilms: Development, dispersal, and therapeutic strategies in the dawn of the postantibiotic era. Cold Spring Harb. Perspect. Med. 2013, 3, a010306. [CrossRef]

98. Tkachuk, N.; Zelena, L.; Lukash, O.; Mazur, P. Microbiological and genetic characteristics of Bacillus velezensis bacillibactinproducing strains and their effect on the sulfate-reducing bacteria biofilms on the poly(ethylene terephthalate) surface. Ecol. Quest. 2021, 32, 119-129. [CrossRef]

99. Kishikawa, H.; Kamimura, T.; Soga, Y. Development of polypropylene coated steel pipe for high temperature service. Sumitomo Search 1996, 58, 1-9.

100. Lueghamer, A.; Ratschmann, E. Polypropylene Piping Systems-A Long Term Solution in a Corrosive Environment. In Proceedings of the CORROSION 2006, San Diego, CA, USA, 11-16 March 2006.

101. Tkachuk, N.; Zelena, L. Bioplivky sulfatvidnovliuvalnykh bakterii na poverkhni materialiv za vplyvu riznoi kilkosti batsylibaktynu. In Proceedings of the III International Conference on European Dimensions of Sustainable Development, Kyiv, Ukraine, 11 June 2021; NUFT: Kyiv, Ukraine, 2021; pp. 64-65. (In Ukrainian)

102. Donlan, R.M. Biofilms: Microbial life on surfaces. Emerg. Infect. Dis. 2002, 8, 881-890. [CrossRef] [PubMed]

103. Rajkumar, M.; Ae, N.; Prasad, M.N.V.; Freitas, H. Potential of siderophore-producing bacteria for improving heavy metal phytoextraction. Trends Biotechnol. 2010, 28, 142-149. [CrossRef] [PubMed]

104. De Serrano, L.O. Biotechnology of siderophores in high-impact scientific fields. Biomol. Concepts 2017, 8, 169-178. [CrossRef] [PubMed]

105. Khan, A.; Singh, P.; Srivastava, A. Synthesis, nature and utility of universal iron chelator-Siderophore: A review. Microbiol. Res. 2018, 212-213, 103-111. [CrossRef]

106. Pal, R.; Hameed, S.; Sharma, S.; Fatima, Z. Influence of iron deprivation on virulence traits of mycobacteria. Braz. J. Infect. Dis. 2016, 20, 585-591. [CrossRef]

107. Simões, L.C.; Simões, M.; Vieira, M.J. Biofilm interactions between distinct bacterial genera isolated from drinking water. Appl. Environ. Microbiol. 2007, 73, 6192-6200. [CrossRef]

108. Gademann, K.; Kobylinska, J.; Wach, J.Y.; Woods, T.M. Surface modifications based on the cyanobacterial siderophore anachelin: From structure to functional biomaterials design. Biometals 2009, 22, 595-604. [CrossRef]

109. Little, B.; Mansfeld, F. Passivity of stainless steels in natural seawater. In Proceedings of the H.H. Uhlig Memorial Symposium; Mansfeld, F., Asphahani, A., Bohni, H., Latansion, R., Eds.; The Electrochemical Society, Inc.: Pennington, NJ, USA, 1995; Volume 94, pp. 42-52.

110. McCafferty, E.; McArdle, J.V. Corrosion inhibition of iron in acid solutions by biological siderophores. J. Electrochem. Soc. 1995, 142, 1447-1453. [CrossRef]

111. Rajala, P. Microbially-Induced Corrosion of Carbon Steel in a Geological Repository Environment; Julkaisija-Utgivare Publisher: Helsinki, Finland, 2017; 86p.

112. Little, B.J.; Lee, J.S.; Ray, R.I. The influence of marine biofilms on corrosion: A concise review. Electrochim. Acta 2008, 54, 2-7. [CrossRef]

113. Pérez-Miranda, S.; Zamudio-Rivera, L.S.; Cisneros-Dévora, R.; George-Téllez, R.; Fernández, F.J. Theoretical insight and experimental elucidation of desferrioxamine B from Bacillus sp. AS7 as a green corrosion inhibitor. Corros. Eng. Sci. Technol. 2020, 56, 93-101. [CrossRef]

114. Javaherdashti, R.; Alasvand, K. Biological Treatment of Microbial Corrosion: Opportunities and Challenges, 1st ed.; Elsevier Science: Saint Louis, MO, USA, 2019; 156p.

115. Zanna, S.; Seyeux, A.; Allion-Maurer, A.; Marcus, P. Escherichia coli siderophore-induced modification of passive films on stainless steel. Corros. Sci. 2020, 175, 108872. [CrossRef] 